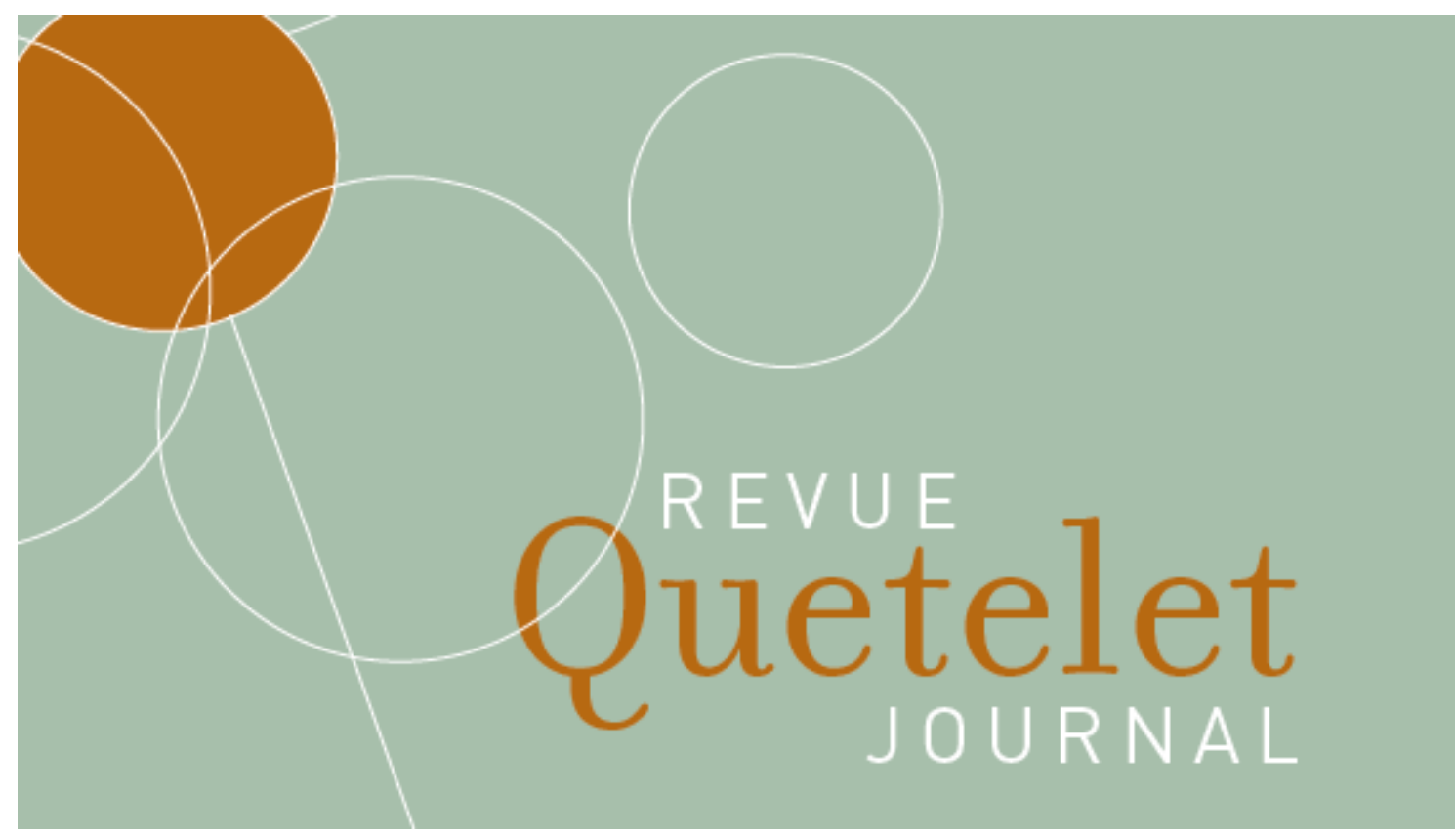

Vol. 8, n², 2020, pp. 61-99

DOI : $10.14428 /$ rqj2020.08.02.02

ISSN: 2593-9157

\title{
1997-2017: An assessment of two decades of immigration in Belgium
}

Sophie Vause

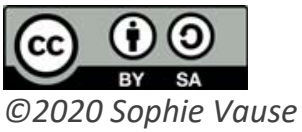

This work is licensed under a Creative Commons Attribution-NonCommercial 4.0 International License. You can share, adapt the material for non-commercial purposes provided that you give appropriate credit and indicate if changes were made. For details see https://creativecommons.org/licenses/by-sa/4.0/

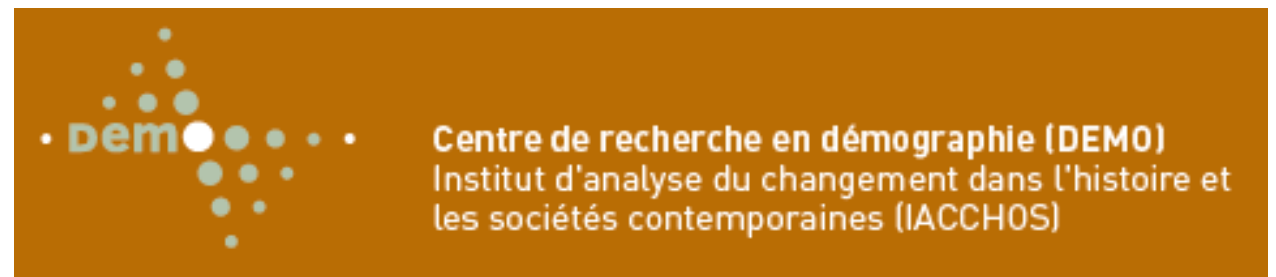





\title{
1997-2017: An assessment of two decades of immigration in Belgium
}

\author{
SOPHIE VAUSE ${ }^{1}$
}

\begin{abstract}
Résumé
Aujourd'hui plus qu'hier, présenter des chiffres clairs sur l'immigration constitue une nécessité, mais également un défi. Cet article tente de démêler quelques chiffresclés pour apporter un éclairage sur les flux récents d'immigration et d'asile en Belgique. Ces dernières années, le nombre d'entrées d'étrangers a atteint un niveau historiquement élevé. En 2017, près de 140000 immigrations internationales ont été enregistrées. Les citoyens de l'UE représentent plus de la moitié de ces immigrations. Derrière une tendance migratoire globalement en hausse depuis la fin des années 1990, des logiques migratoires assez contrastées peuvent être dégagées. Depuis 2014 par exemple, les Français se font devancer par les Roumains dans les immigrations étrangères vers la Belgique, depuis lors en tête de classement. Depuis plus de cinquante ans l'immigration marocaine figure parmi les principaux flux d'immigration, mais cette migration ancienne est freinée récemment par un regroupement familial rendu plus difficile. Les immigrations de Syriens enregistrées en Belgique ont par contre fortement augmenté, plaçant la Syrie dans le top cinq des pays d'origine des immigrants en 2016 et 2017.
\end{abstract}

\section{Mots-clés}

Immigrations, nationalité, origine des migrants, tendances migratoires, asile.

\section{Abstract}

Today more than yesterday, presenting clear immigration Figures is a necessity, but also a challenge. This article aims to unravel some key Figures to shed light on recent immigration and asylum flows in Belgium. In recent years, the number of entries of foreigners in Belgium has reached a historically high level. In 2017, nearly 140'000 international immigrants were registered. EU citizens accounted for more than half of these immigrants. Behind a migration trend that has been on the rise since the end of the 1990s, contrasting migratory patterns can be identified. Since 2014, for example, the French have been more numerous than Romanians among foreign immigrants to Belgium and have been at the top of the list ever since. For more than fifty years Moroccan immigration has been one of the main immigration flows, but

1. Myria, Brussels, Belgium. 
this long-standing migration has recently been slowed down by family reunification, which has become more difficult. Registered Syrian immigration to Belgium has risen sharply, placing Syria in the top five countries of origin of immigrants in 2016 and 2017.

\section{Keywords}

Immigration, nationality, origin of migrants, migration trends, asylum.

In 2017, nearly 140 '000 foreign immigrants were registered in Belgium (source: Statbel2). According to available national statistics, this figure has more than doubled in the space of twenty years. Emigration is also on the rise, reflecting an overall increase in mobility. How can these trends be interpreted in the long-term context of international migration in Belgium?

From the end of the 19th century until the First World War, the number of foreign immigrants in Belgium increased considerably, with a preponderance of border migration. They were joined by by migrants from other European countries as well as from the Maghreb during the interwar period and after the Second World War. Italians, and later Moroccans and Turks, were important in the migration flows for this period. Until the 1970s, this migration was encouraged by the Belgian state, which organised it on the basis of recruitment campaigns and through bilateral agreements with non-European countries. Migrant workers were welcome, although their presence in Belgium was considered temporary (Eggerickx, Hermia, 2005; Eggerickx, 2006).

After the oil shock in the 1970s and the economic recession experienced in most European countries, the Belgian state decided to put an end to labour immigration as early as 1973 (Morelli, 2004). This decision led to a decrease in the number of foreign immigrants and even a negative net migration for the foreign population in 1982 and 1983. However, from 1984 onwards, inflows increased again, exceeding outflows and rebalancing net migration flows (Myria, 2013). This resumption of entry into Belgium was primarily the result of family reunification authorised by the Belgian government. Given the difficult living conditions in countries of origin, migrant workers in Belgium seek to settle there more permanently, and a large proportion of them use family reunification to bring in their spouses and children. As a result, the migrant profile is diversifying: the foreign population is gradually getting older and its female proportion is increasing (Eggerickx, 2006).

2. Belgian Statistical Office, https://statbel.fgov.be/en. 
This resumption of overall immigration in the 1980s also corresponded to a resumption of immigration of Europeans, which had been affected by the energy crisis of the 1970s and the Cold War (Van Mol, de Valk, 2016). A third major phenomenon then came into play: a spectacular increase in the number of asylum applications from East European countries from 1989 after the fall of the Berlin Wall. Until recently migration for political as well as economic and humanitarian reasons was increasing, partly due to the growing socio-economic gap between countries in the Global South and the Global North (Lafleur et al., 2015).

Belgium shares a relatively common migration history with its neighbouring countries: most European countries have indeed gone through the same periods described above. This is particularly the case for France, Germany and the United Kingdom, which, together with Belgium, were among the European countries with the largest immigrant populations in the 1950s (Van Mol, de Valk, 2016). At the same time, the decolonisation process of the 1960s led to considerable migration flows to the former European colonial powers: from the Democratic Republic of Congo to Belgium, from North Africa to France, from Indonesia to the Netherlands, and from Kenya, India and Malaysia to the United Kingdom.

The 1973-1974 oil crisis had a considerable impact on the European economic and migration landscape, with most countries affected. Switzerland (in 1970) and Sweden (1972) were among the first European countries to halt foreign immigration. They were followed by Germany (1973), then Belgium, the Netherlands, Luxembourg and France (1974). In all these countries, however, these migration policies have contributed to transforming the migration landscape rather than actually slowing or stopping the inflows. Family reunification policies have also been applied in all these countries.

More recently, flows of asylum-seekers have emerged in most European countries, particularly following the fall of the Berlin Wall in 1989 and the end of the communist regimes in Eastern Europe leading to the wars in the former Yugoslavia (Salt, 2011). In this respect, Germany was quickly established as the country receiving the most asylum applications in Europe. This German peculiarity has been maintained over time (Hatton, 2004; EASO, 2019). From the 1980s significant increases were also observed in Belgium, the Netherlands and the United Kingdom (Van Mol, de Valk, 2016). The nationality of asylum-seekers has gradually changed in most Western countries, with an increasing influx since the early 2000s of Afghans, Iraqis and more recently Syrians. 
In parallel with these trends shared by the countries of Western Europe, other migratory patterns have developed in the countries of Southern Europe. Greece, Italy, Portugal and Spain in particular have long been countries of emigration. It was only from the 1990s that migration flows were also increasingly directed towards these countries (Salt, 2011). This trend reversal for these countries is mainly explained by the combination of two elements: economic growth and a falling birth rate, resulting in a shortage in the labour market (Castles et al., 2014). Southern European countries have therefore gradually become attractive for low-skilled workers taking up jobs with difficult working conditions.

More recently, the successive accessions of new states into the European Union have contributed to the creation of an increasingly large area of intra-European mobility. In this respect, the role of Brussels as the capital of Europe should be noted: the presence of European institutions in Belgium has contributed to the European foreign presence there (Eggerickx, 2006). By contrast, migration from non-EU countries to the Schengen Area has become more restricted, or at least admission has become more restrictive (Van Mol, de Valk, 2016).

Ultimately, the growth in immigration in Belgium is accompanied by an unprecedented diversification of immigrant profiles (Martiniello et al., 2010). While the history of migration in Belgium is relatively well documented, the more recent period is less studied. However, recent legislative, political and societal changes as well as international migration events justify an examination of the last twenty years. This article aims to draw a portrait of the last two decades of migration in Belgium and highlight the main changes ${ }^{3}$. The first section deals with the definitions and data used and their methodological specificities. The second section presents recent trends in migration flows in Belgium. The various components of immigration flows are detailed, making it possible to highlight two particular categories: persons recognised as refugees and regularised persons. An analysis of migration dynamics by immigrant origin is also presented. The third section deals with migration patterns. Behind the major recent trends, it is important to also draw attention to changes in terms of migrant profiles. To this end, the paper focuses on four nationalities that can be considered emblematic of the diversity of migration over these two decades in Belgium. A fourth and final section provides some conclusions.

3. This article is partly based on several publications produced for Myria (the Belgian Federal Migration Centre). 


\section{Definitions, data and methods}

\section{The National Register}

In Belgium, the National Register (NR) is the main source of information for understanding migration. From this source, Statbel produces and disseminates reliable, official and relevant figures, including demographic data. This article is based primarily on a descriptive analysis of data on migration flows (Box 1).

Every individual staying in Belgium for more than three months is required to register with his or her commune of residence 4 . Similarly, anyone leaving the country for a period of more than three months is required to declare his or her departure. This information is centrally stored in the NR, which makes it possible to record entries into and exits from Belgian territory (Box 2). The reliability of this information depends on people declaring their comings and goings as they enter and/or leave Belgian territory. For this reason, caution is called for in the analysis of migration statistics, especially in terms of short-term stays and emigration, which are comparatively less well reported.

\section{Box 1 Migration flows versus migrant stocks}

The various data available generally make it possible to approach the phenomenon of international migration from two different angles: through migration flows or in terms of migrant stocks (Myria, 2015). These concepts can be defined as such:

Migration flows refer to all entries (immigrations) and exits (emigrations) of individuals into and out of a country over one year. This type of data requires continuous recording and has the advantage of providing a comprehensive view of the migration phenomenon, allowing general trends to be observed over varying periods of time.

Migrant stocks or presence of migrants ${ }^{5}$ refers to the number of immigrants present in a country on a specific date. In other words, it is a snapshot of the immigrant population at a given time. From this type of data, it is also possible to derive

4. Article 1 of the Act of 19 July 1991 on population registers, identity cards, alien cards and residence documents.

5. It is also possible to produce other statistics on the stock of foreigners or persons of foreign origin, but under the criterion of nationality or citizenship at birth, rather than country of birth. In this chapter, we will essentially address the question from the angle of migration flows. 
changes from one date to another, but the information then consists more of an estimate of migration flows at different points in time.

\section{Box 2 The National Registry}

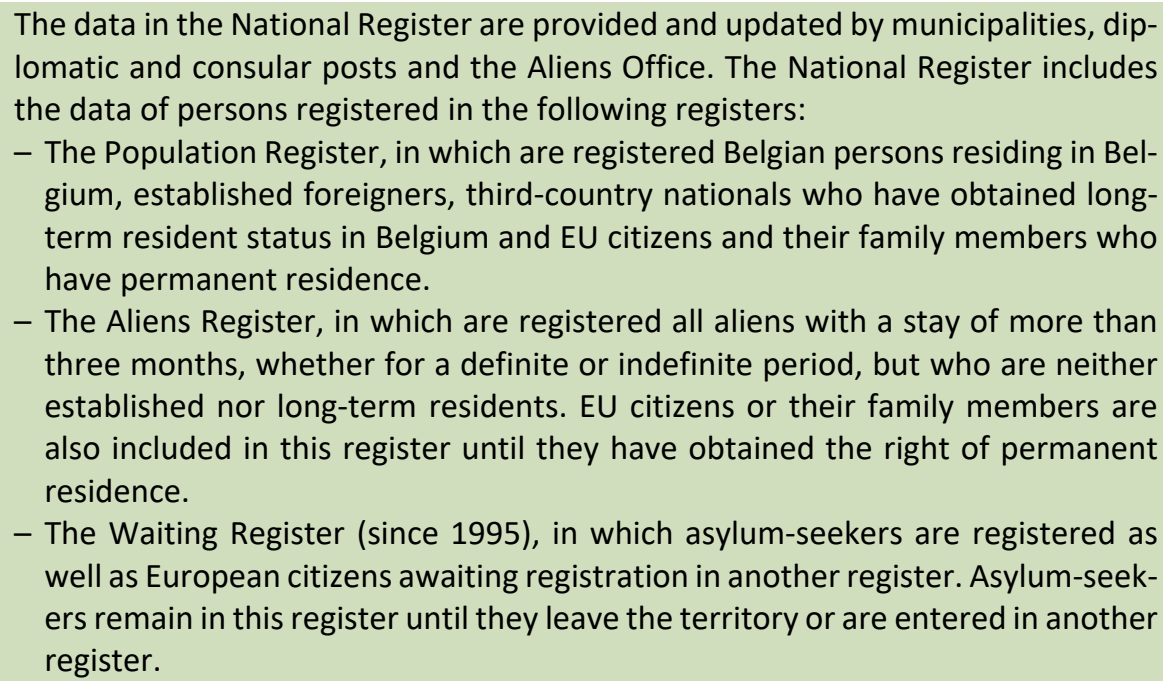

- The Aliens Register, in which are registered all aliens with a stay of more than three months, whether for a definite or indefinite period, but who are neither established nor long-term residents. EU citizens or their family members are also included in this register until they have obtained the right of permanent residence.

- The Waiting Register (since 1995), in which asylum-seekers are registered as well as European citizens awaiting registration in another register. Asylum-seekers remain in this register until they leave the territory or are entered in another register.

As far as legal entry is concerned, it is in the interest of foreigners to comply with the obligation to register with the NR because it facilitates a number of everyday procedures (opening a bank account, social security, etc.). As a result, non-declarations are rare for migrants who are considering a long-term stay. On the other hand, the reliability of emigration statistics is more questionable. Declaring one's departure can be burdensome or can, in some cases, be intentionally avoided by those who wish to retain certain benefits linked to registration (right to social security, right of residence, etc.) or who fear losing them. Individuals whose departure has been ascertained in one way or another by the authorities, or whose residence permit has expired, are struck off the $\mathrm{NR}^{6}$. They are then counted under the category of «de-registered» and are added to reported emigration figures to reflect international emigration (Box 3). While the method has the merit of attempting to correct non-reporting problems, these removals sometimes occur late. In practice, not all individuals who leave

\footnotetext{
6. For certain categories of migrants (e.g. Erasmus students), the Act provides for the possibility of leaving for more than three months and keeping their home, which enables them to maintain their rights to family allowances, for example.
} 
the municipality are systematically deregistered, and not all de-registered persons have necessarily left the municipality in which they resided. Between 1988 and 2006, Statbel considered that when people were de-registered and then re-registered in the NR, the deregistration was undue. Statbel therefore advocated that they should not be taken into account in international immigration but rather excluded from emigration figures. However, this method was abandoned in 20077, when Statbel decided to consider these re-registrations as international immigration. Since then, «re-enrolments of de-registered immigrants» have been added to declared immigrants, which has had the effect of increasing not only inflows but also outflows. These methodological changes, which are not without consequences for the estimation of migration flows, aim to calculate the components of the flows in such a way as to reflect the administrative reality as closely as possible. It should be noted, however, that a (probably significant) proportion of these de-registrations and reregistrations does not refer to real population movements but rather reflects the administrative background of some migrants. A foreigner may, for example, lose their right of residence and be struck off the NR, only to be regularised and re-registered some time later.

In addition to these reporting problems, other adjustments to the data have been made to account for a particular population: that of asylumseekers. Until 1995, all asylum-seekers were registered in the municipal registers, as were all foreigners. However, since the creation of the Waiting Register on 1 February 1995, they have been registered separately in this new register, and only moved to municipal registers when they obtain resident status. Their migratory movement is therefore only recorded at the time of recognition of resident status. In other words, these immigrations are recorded with a time lag reflecting the lag between their physical entry into Belgium and their inclusion in the statistics. While this methodology does not completely hide the share of asylum-seekers in immigration statistics, it is clear that it does not fully reflect the reality of migration.

7. This old method posed a number of problems, including the fact that the emigration of certain nationalities was becoming negative. This could be the case for nationalities whose declared emigration was relatively low, but for which there was a higher number of undue deregistrations. 
Box 3 Calculations of international emigration from and immigration to Belgium

\begin{abstract}
International immigration and emigration are respectively the sum of three components (according to the methodology followed by Statbel):

Immigration = reported immigration + reinstatements

of deregistered immigrants + changes in register

- Reported immigration is all entries into the territory for stays of more than three months reported by individuals during the year under study. This is, of course, the main component of immigration (in 2017, declared immigration accounted for $81 \%$ of international immigration as calculated by Statbel).

- Reinstatements of de-registered immigrants are persons who have been wrongly removed from the register (for example, because they were found to be missing) and who have been reinstated in the register. They account for just under $8 \%$ of all immigrants in 2017.

- Changes in the register reflect persons who have been moved from the Waiting Register to another register because they have been recognised as refugees or regularised on another basis. They account for just over $11 \%$ of all immigrants in 2017.

Emigration = reported emigration + automatic de-registrations + register changes

- Reported emigration is all exits from the territory for more than three months reported by individuals during the year under study. In 2017, declared emigration accounted for $49 \%$ of international emigration as calculated by Statbel.

- Automatic de-registrations are persons whose departure has been recorded by the authorities or whose residence permit has expired. It is therefore by means of a statistical adjustment that these exits are accounted for as emigrations. They account for $50 \%$ of emigration in 2017 . This means that slightly more people have been delisted than those who report leaving the country.

- Register changes refers to persons moved from a register (the Population Register or Aliens Register) to the Waiting Register. This component accounted for less than $1 \%$ of emigration in 2017.
\end{abstract}

Finally, since 2010, two new changes have been applied by Statbel in the estimation of migration flows:

- Firstly, two categories have been created with regard to register changes: on the one hand, shifts from the Waiting Register to another population register are recorded in immigration movements; on the other, shifts from another population register to the Waiting Register are recorded in emigration movements. The former are the most frequent cases, since they involve asylum-seekers who are recognised or authorised to stay on another basis, while the latter represent individuals recorded in the Aliens Register and who, for one reason or another, 
submit an asylum application at the end of a legal stay in Belgium ${ }^{8}$. Prior to 2010, only the balance of these two categories was posted for consideration as immigrants.

- Another amendment revolves around the definition of persons de-registered or reinstated. Only persons who are de-registered over the course of the year and not re-registered the same year are considered to be automatically deregistered. They are therefore accounted for as emigrants. Similarly, only persons who were struck off in previous years and re-enrolled in the reference year are included in re-enrolments and are therefore added to the immigrant count. The purpose of this change is to avoid artificially inflating these categories by not counting persons who were deregistered and re-registered in the same year. This methodological change, which was effective from 2010, is reflected in recent developments in these categories ${ }^{9}$.

\section{The first residence permits}

In order to better understand the profiles of the migrants, it is interesting to know the reasons why these people arrived in Belgium. In this respect, the Aliens Office provides statistics on first residence permits. This information is contained in the NR for both EU and non-EU citizens. It should be noted, however, that the study of migration patterns is a complex undertaking. Foreigners entering the territory must declare their arrival at their commune of residence and are issued a residence permit on the basis of the type of visa they have. That said, the reasons that drive individuals to migrate can be manifold, and may not fit easily into any of the established administrative categories. This database therefore makes it possible to study the legal reasons for migration but not the personal ones in all their nuances. Let us point out some of the limitations of these data. As is the case in immigration flow statistics, asylum-seekers are not recorded as such in the figures on first residence permits. They are included in the statistics only when they are recognised as refugees or are granted subsidiary protection, or if they obtain a first residence permit on another basis. Moreover, persons who are granted a first residence permit for family reasons are not exclusively beneficiaries of family reunification from abroad, but all persons whose first residence permit is obtained for family reasons. Among these are the several thousand children

8. An example might be a student legally resident in Belgium who, at the end of their studies and therefore the validity of their residence permit, cannot return to their country of origin because of political conditions there. They may then be required to submit an application for international protection.

9. For more details on the effects of methodological changes on immigration and emigration curves, see Myria (2013). 
born in Belgium every year who are granted a first residence permit because of their parents' status. In 2016, 15'888 of the 50'928 first residence permits (31\%) were issued to descendants born in Belgium.

Ultimately, the statistics on first residence permits make it possible to study in some respects the legal reasons for migration. However, they do not fully cover immigration flows, since some categories of individuals receive a first residence permit even though they did not migrate (i.e., they are children born in Belgium) or they arrived earlier (i.e., beneficiaries of international protection).

\section{Box 4 Refugee status and subsidiary protection}

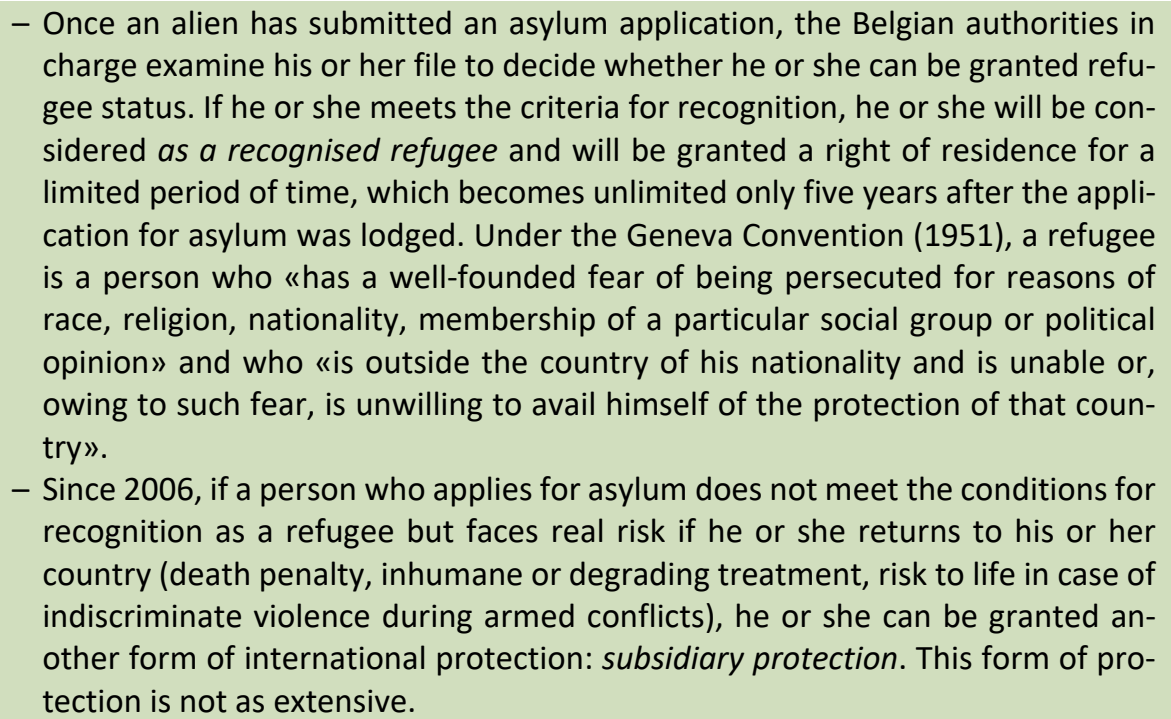

\section{Trends in migration flows in Belgium: 1997-2017}

\section{The end of the 1990s, marked by increasing foreign immigration}

In recent years, the number foreigners entering the country reached a historically high level (Figure 1). In 2010, 2011 and 2017, nearly 140'000 international immigrants were registered annually. Although some recent years have seen lower inflows, these «spikes» in immigration far exceed previous peaks in the 1950s and 1960s. To provide a point of comparison, one must consider the number of reported immigrants, without 
accounting for changes of register and re-registered persons who had been removed from the register ${ }^{10}$. In the more distant past, two major peaks (in 1948 and 1964) of just over 83,000 legal immigrants had been recorded ${ }^{11}$, compared with about $110^{\prime} 000$ in recent years ${ }^{12}$. Moreover, the context in which these immigrations have taken place has changed considerably. Indeed, during the post-war period as well as in the 1960s, foreign immigration was favoured by the Belgian state, and the peaks observed during this period of «labour recruitment» can be considered as cyclical $^{13}$. Conversely, the increase observed over the last twenty years appears more structural than cyclical. Moreover, it is taking place in a context that is much less favourable to the opening of borders.

After the first oil shock, the decision taken by the Belgian state in 1974 to put an end to labour immigration clearly led to a decrease in the number of foreign immigrants. However, labour immigration did not cease, and from 1984 onwards, inflows began to increase again, though for reasons other than labour. First, the increase reflects the growth of what is generically referred to as "family reunification ${ }^{14}$. These are, on the one hand, foreigners already established in Belgium whose family members who have remained in the country decide to immigrate and, on the other hand, foreigners and Belgians established in Belgium who marry foreigners who thereby obtain the right to enter Belgium. This resurgence of immigration in the 1980s also corresponds to a resumption of immigration of European citizens, which had been affected by the crisis of the 1970s (Morelli, 2004). From the 1980s onwards, the accession to the EU of Greece (1981), followed by Spain and Portugal (1986), stimulated intra-European migratory exchanges.

10. As a reminder, these last two categories are not available for years prior to 1988 for those re-registered who had been de-registered, and prior to 1995 for changes of register. It is important to detail these different categories in order to compare figures that are comparable over time, i.e., that would refer to the same definition for different periods.

11. The exact figures are 83'741 in 1948 and 84'490 in 1964.

12. The exact figures are 113'582 in 2010, 117'948 in 2011 and 113'211 in 2017.

13. It should be noted that bilateral agreements between Belgium and non-European countries were not necessarily the result of active recruitment by the Belgian state, but they did provide a framework for proactive approaches on the part of interested workers (Martens, 1976).

14. This notion has evolved considerably over time, but its beginnings were already discernible. 
FIGURE 1 Immigrant flows of foreigners into Belgium, 1950-2017

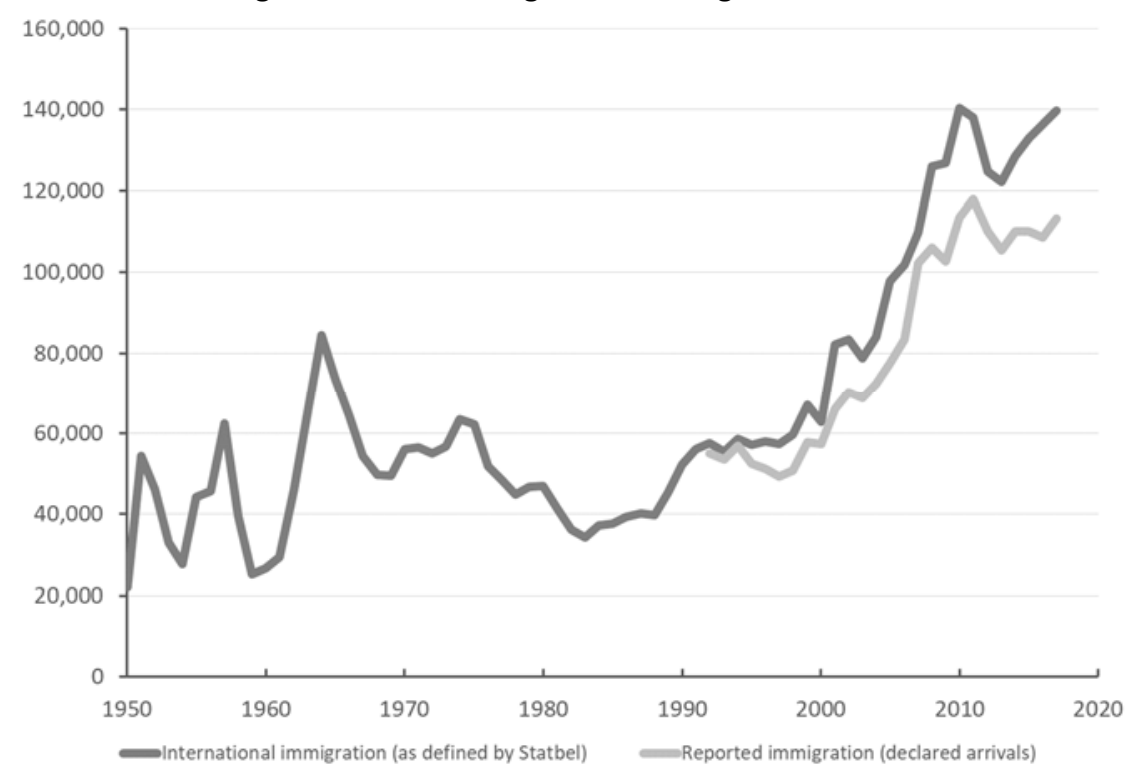

Data source: National Register, Statbel, author's calculations.

The beginning of the 1990s saw an increase in the number of new arrivals due to family reunification and European immigration, but a third major phenomenon also came into play: the significant increase in asylum applications from 1989 onwards. A drop in asylum applications from 1994 to 1997 led to a temporary reduction in entries, a reduction amplified by the exclusion of asylum-seekers from immigration statistics from 1995, when the Waiting Register was created (Box 2) (the reduction in entries was therefore rather artificial from 1995 to 1998). Nevertheless, inflows began to rise sharply again in 1998, peaking in 2001 and 2002; almost $46^{\prime} 000$ people lodged a first asylum application in 2000 (see below).

The end of the 1990s and the beginning of the 2000s marked a real acceleration in migratory exchanges to and from Belgium. That said, the inflow curve is not linear, and behind this global trend lie highly diverse migration dynamics. 


\section{A largely positive migratory balance}

The mobility of foreigners is two-way: they enter Belgian territory and they leave Belgian territory. Some settle permanently while others continue on to other destinations or return to their country of origin. Although Belgium is now primarily a country of immigration, emigration has also risen sharply, particularly since the early 2000s. This trend reflects a general increase in mobility.

FIGURE 2 Trends in immigration and emigration flows of foreigners and in net migration, 1997-2017

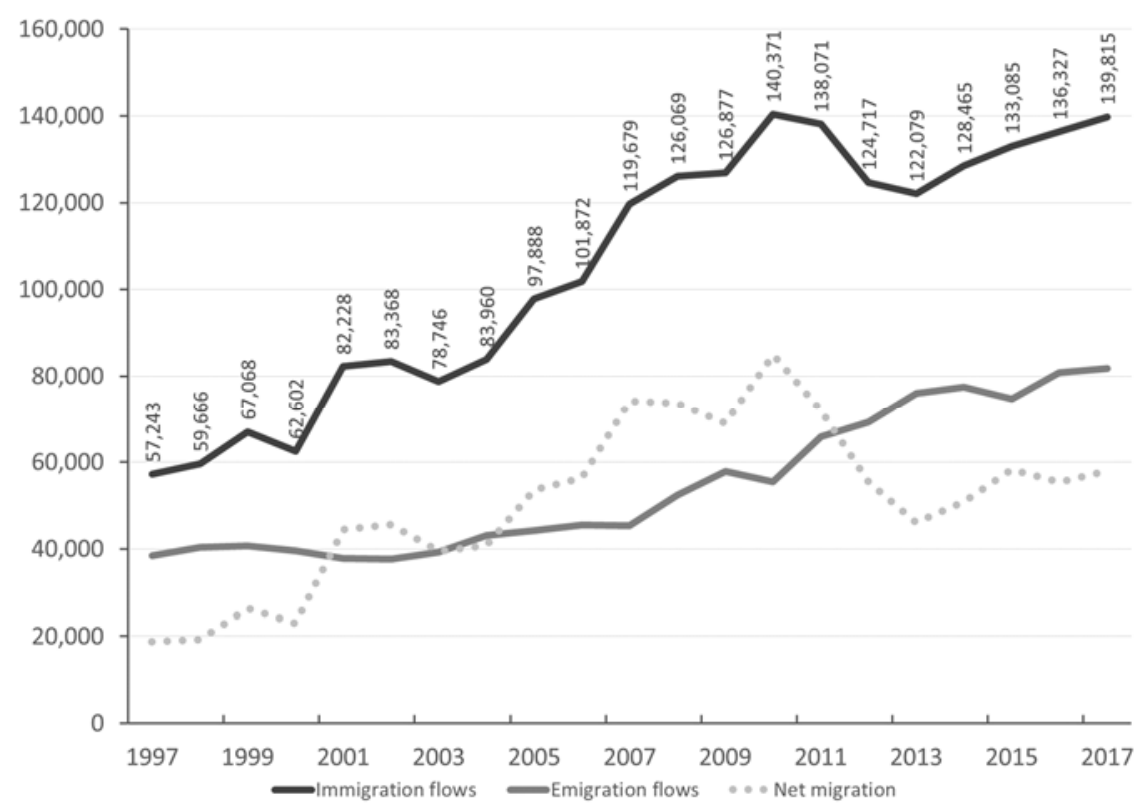

Data source: National Register, Statbel, author's calculations.

For the reasons mentioned above, statistics on emigration are not as good as those on immigration. However, they give an idea of the magnitude of departures of foreigners. In general, emigration of foreigners is much 
lower than immigration, resulting in a positive and increasing net migration ${ }^{15}$ over the period 1997-2010. In recent years (2011-2017), immigration growth has slowed while emigration has continued to grow, resulting in lower net migration (Figure 2).

The impact of regularisations and asylum on immigration flows

International immigration of foreigners to Belgium is the result of three components: declared entries, re-enrolments of persons who were struck off the register, and changes in register (transfer from the Waiting Register to another register) (Box 3).Figure 3 details the respective importance of these components over the past 20 years. Changes in register account for about $10 \%$ of all immigrants. This is particularly interesting because it allows inclusion in the statistics of migrants who, because of their status, are not included in the reported entries into Belgium. These are mainly illegal residents, or asylum-seekers not yet recognised as refugees who have had their residence status regularised, or asylum-seekers who have been recognised as refugees or granted subsidiary protection at the end of their asylum procedure.

The evolution of the number of register changes is shown in Figure 4 showing four peaks over the last two decades: 2001, 2005, 2010 and 2016. The first three peaks essentially correspond to regularisation operations while the last is more a reflection of an increase in recognition of international protection.

15. Net migration is defined as the difference between immigration and emigration over a defined period. A positive net migration balance therefore indicates that the number of entries during this period is greater than the number of exits, and vice versa in the case of a negative balance. 


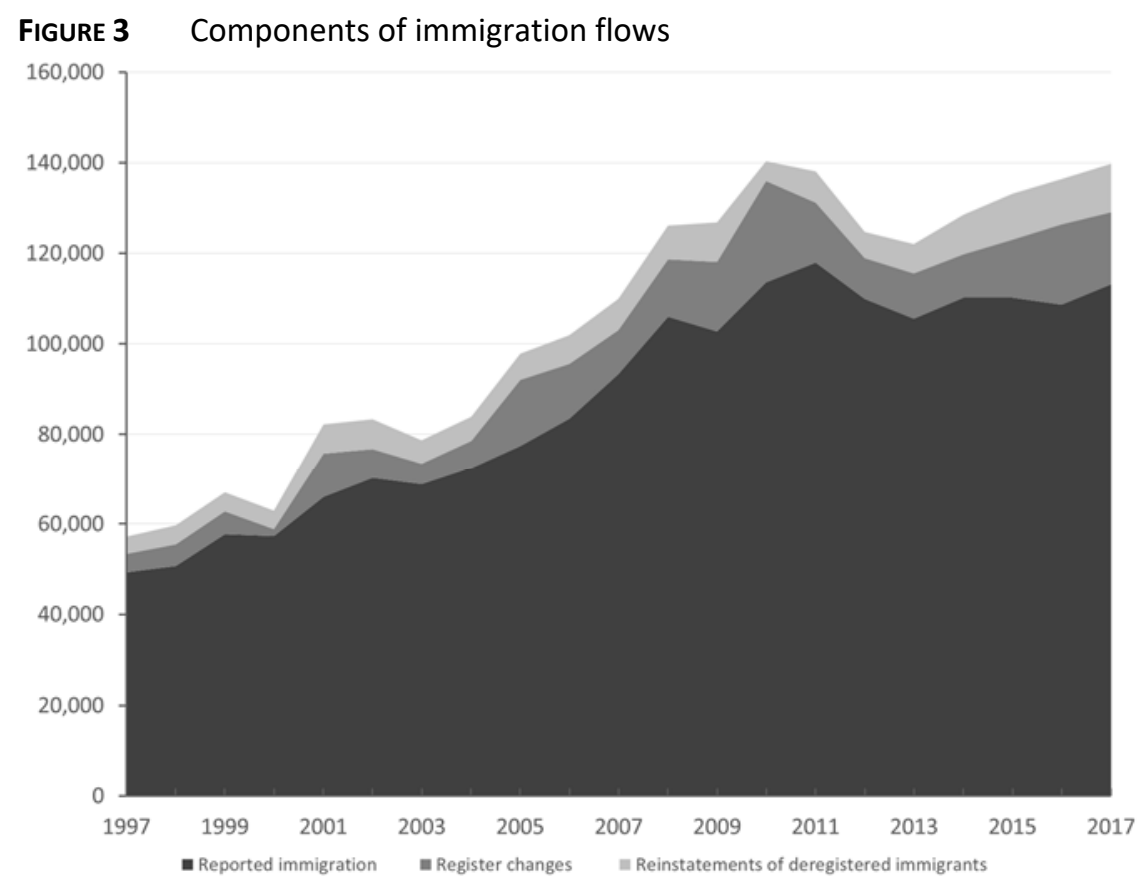

Data source: National Register, Statbel, author's calculations.

\section{FIGURE 4 Register changes (from Waiting Register to another register)}

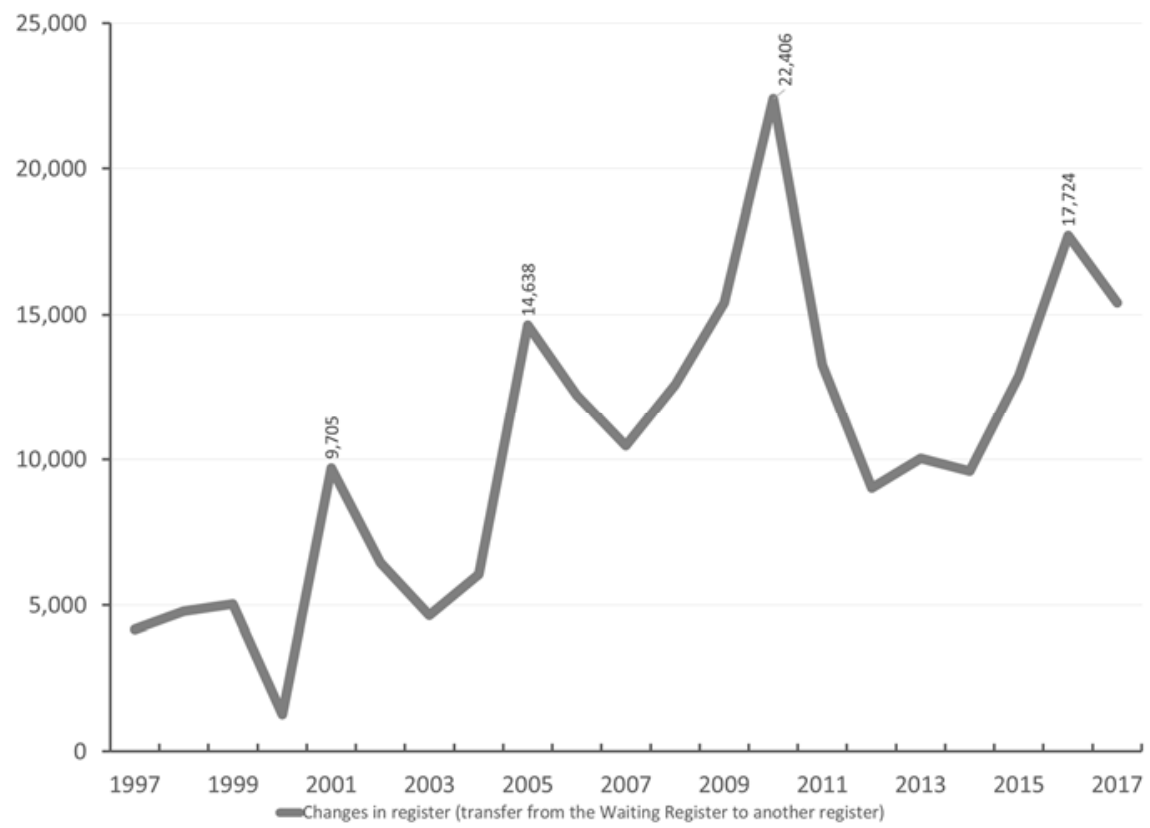

Data source: National Register, Statbel, author's calculations) 


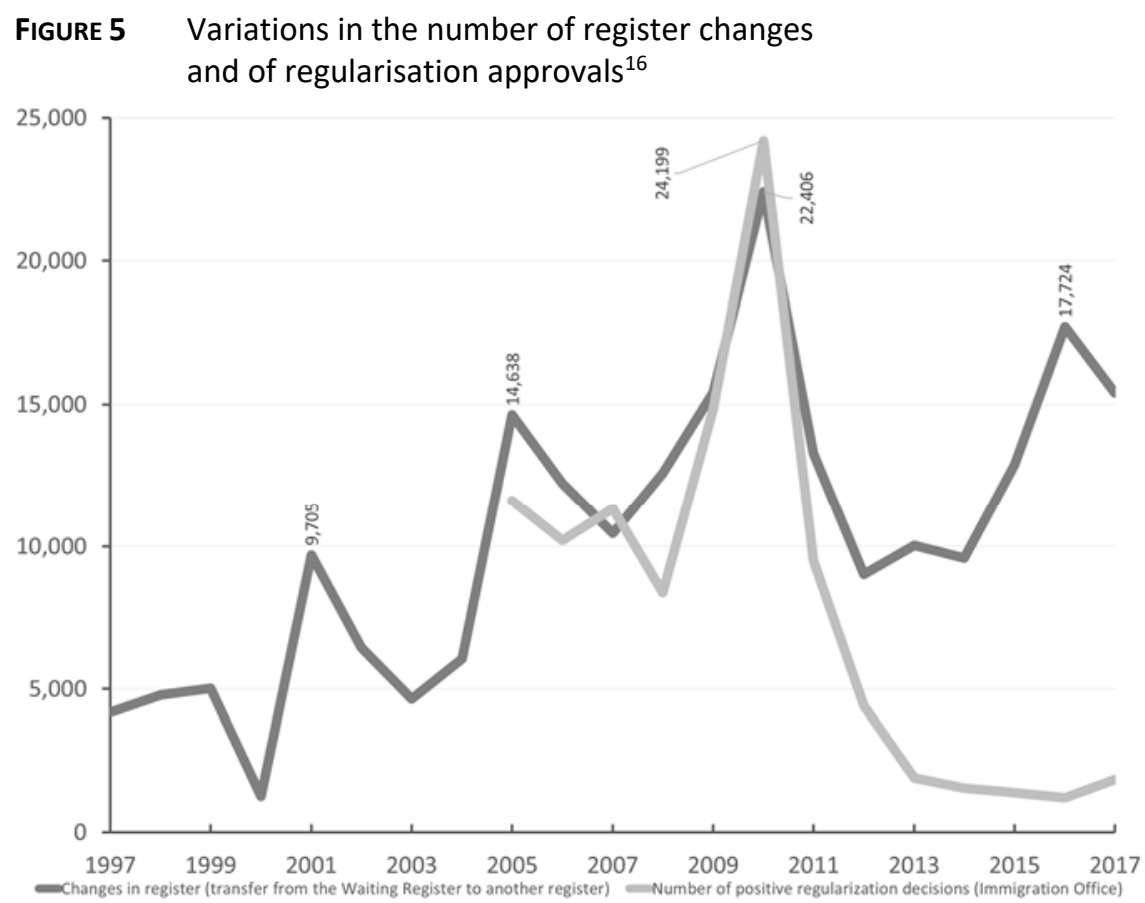

Data sources: National Register, Statbel and Office for Foreigners, author's calculations.

\section{The 1999 and 2009 regularisations}

Although applications for residence permits must be, in principle, submitted from abroad, the Aliens Act of 15 December 1980 nevertheless provides for the possibility of submitting such an application while in Belgium under «exceptional circumstances». These include humanitarian or medical reasons. The Act does not specify what qualifies as exceptional circumstances, except by excluding certain circumstances. The minister has broad discretionary powers to issue permits. In addition to the Act of 15 December 1980, two other specific acts were enacted in Belgium in 1999 and 2009.

16. Both curves show that in some years (2007 and 2010) there are more regularised persons (respectively 11'335 and 24'199) than changes in register (respectively $10^{\prime} 468$ and $22^{\prime} 406$ ). This is probably due to the fact that the change of residence status is entered in the register with a delay in relation to the decision taken by the Immigration Office, a phenomenon that is all the more evident following a large number of regularisations. 
FIGURE 6 Variations in the number of register changes and in the number of persons recognised as refugees or benefiting from subsidiary protection

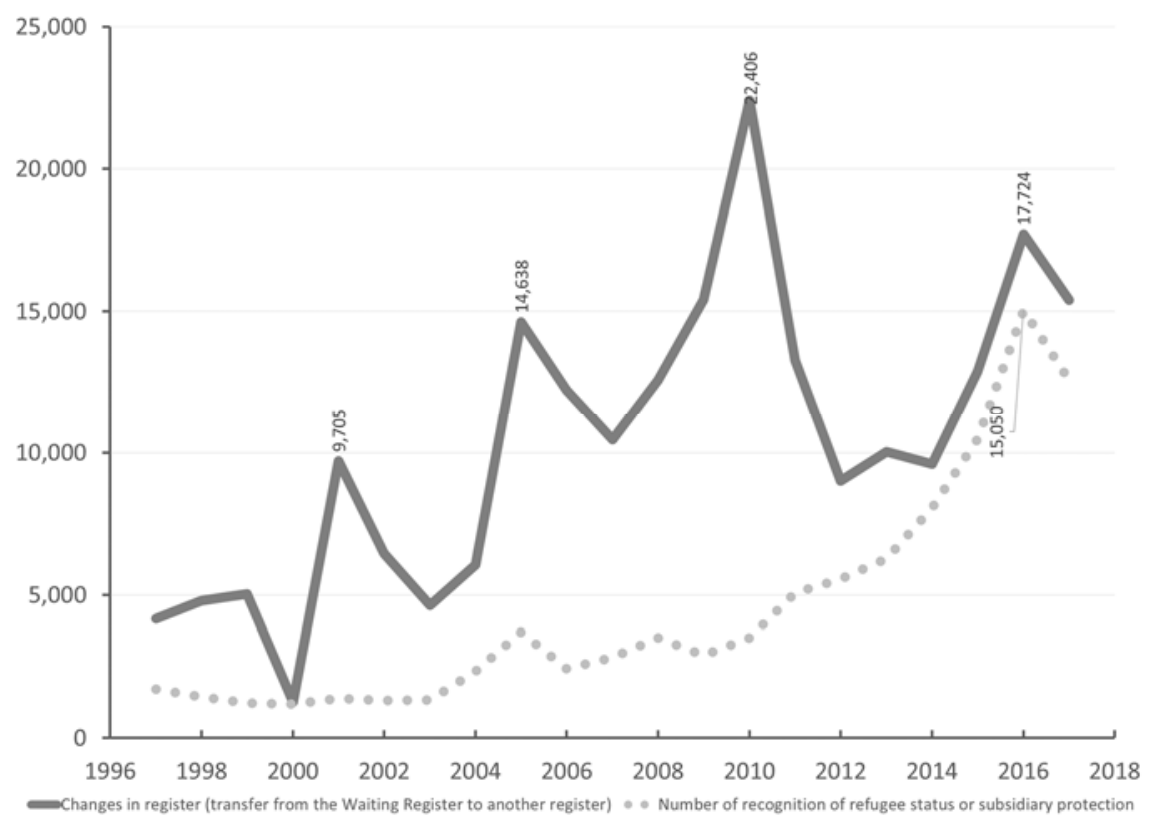

Data sources: National Register, Statbel and the Office of the Commissioner General for Refugees and Stateless Persons, author's calculations.

The 1999 Act

The purpose of the Act of 22 December 1999 on the regularisation of the residence status of certain categories of foreigners was to grant residence permits - in principle of unlimited duration - to persons who were in a precarious or irregular situation on Belgian territory at that time. During this regularisation campaign, more than 32 '000 applications, involving approximately 50'000 people, were submitted to the Regularisation Commission, which was set up on a temporary basis. In addition to these cases, the pending applications of some 3'000 people who had already submitted a regularisation request to the Aliens Office before the campaign were transferred to the Regularisation Commission for processing (according to the criteria of the Act of 22 December 1999). This politically independent commission was tasked with studying the applications and then submitting an opinion to the Minister of the Interior, who then took the decision on whether or not to regularise these persons. This Act established a temporary procedure based on four clear criteria: (1) having 
been the subject of a long-term asylum procedure, (2) being unable to return to their country of origin for reasons beyond their control, (3) being the victim of a serious illness, or (4) being able to demonstrate humanitarian circumstances and having developed lasting social ties in Belgium. This was a temporary operation, and the applications were to be introduced during the month of January. Although the Act set into motion a massive regularisation operation because the criteria were aimed at a large number of illegal immigrants, it was not a collective procedure, since the applications were dealt with individually (Directorate-General for Employment, the Labour Market, 2003).

The peak observed in 2001 on the register change curve (Figure 5) corresponds to the regularisation operation that took place at the beginning of 2000 (on the basis of the 1999 Act). This had a major impact on the figures for 2001, during which a large number of applications meeting the regularisation criteria were processed. In 2005, as part of the management of the large backlog at the General Commission for Refugees and Stateless Persons (CGRA), the then Minister of the Interior pursued a policy of regularisation for cases characterised by a long asylum procedure. While register changes are promising as an indicator for pinning down the number of persons regularised, it has two important drawbacks. Firstly, not all regularised persons are included in these statistics: in particular, foreigners illegally in the country who have never applied for asylum are not counted. Secondly, regularisation decisions do not always lead to the person being entered in the register (Before \& After, 2008).

For these years, annual figures on the number of people regularised are difficult to find. Some authors cite more than $40^{\prime} 000$ people regularised between 2000 and $2005^{17}$ (Before \& After, 2008). In total, between 2000 and 2005, approximately 42'700 people were moved from the Waiting Register to another register. Not all were actually regularised people (since other categories of persons are included in these statistics, such as recognised refugees), but a large proportion of them were in all probability. Among these $42^{\prime} 700$ people, the main nationalities are either from

17. A number of members of Parliament asked for clarification of these figures, particularly specifics by year, but no precise answer has been provided. On the one hand, there is no official document containing these figures for the Regularisation Commission, and on the other hand, the regularisations granted by the Immigration Office were not systematically encoded before 2005 . With regard to the $\mathrm{OE}$, an answer to a parliamentary question states: «At the beginning of 2005, the relevant office was completely reorganised. The statistical system has been developed and adapted, and since 2005 the data have been updated in a uniform manner. Comparable figures are therefore not available for the period of 2000 to 2004» (QVRA 51-120, no. 950, http://www.lachambre.be/QRVA/pdf/ 51/51K0120.pdf). 
Eastern European countries, such as the countries of the former Yugoslavia (16\%) and Russia (11\%), or from Central African countries, mainly Congo (10\%) and Rwanda (6\%).

The 2009 instructions

In the summer of 2009, the Belgian Government published a long-awaited document on the criteria for regularisation. By means of two instructions, it provided for a number of permanent regularisation criteria (one of which, for the first time, is linked to being able to find a job) as well as a temporary measure for persons with a «sustained local anchorage» in Belgium. These persons could then submit an application for regularisation between 15 September and 15 December 200918. In terms of statistics, the Aliens Office has published the number of regularisations according to these criteria for the years 2009,2010 and $2011^{19}$. It is likely that some applications were still processed on the basis of these criteria (especially the permanent criteria) in the years that followed, but the Aliens Office no longer published them from 2012.

The peak observed in 2010 on the curve of register changes (Figure 5) is the consequence of this regularisation operation carried out from July 2009 , and most of the applications were processed over the course of 2010. Of particular note is the importance of the criterion of sustained local anchoring, since in 2010 almost half of all regularisations were granted on this basis. Between 2009 and 2011, the three years mainly affected by this regularisation operation, more than 50'000 register changes took place. As before, not all of these register changes involved regularised persons, but a large proportion of them probably did. The main nationalities affected by these registry changes were Russians (10\%), Congolese (8\%) and Armenians (7\%).

Since 2010, the number of regularised persons has been decreasing each year, with the exception of $2017(1,853)$, which saw a higher number of regularisations than in $2016(1,205)$. That said, the current context is clearly not conducive to further massive regularisations. On its website,

18. On 9 December 2009 - i.e., before the three-month period expired - this instruction was annulled by the Council of State. The Secretary of State in charge declared following this judgment that he would guarantee the legal security of the applicants by continuing to apply the criteria of the investigation - within the limits of his discretionary authority. For more details on the consequences of these policy decisions, see CECLR (2011), Annual Report, pp. 94-101.

19. CECLR (2011), Annual Report, pp. 117-126. 
the Aliens Office states that the Belgian Government's instruction recognises the exceptional nature of the regularisation procedure: «The agreement no longer provides for collective regularisation. This means that the Aliens Office will not consider any request for collective regularisations in the coming years». ${ }^{20}$

2000 and 2015: Years marked by asylum flows

Since the establishment of the Waiting List in 1995, asylum-seekers are included in immigration flows only when they are granted some form of international protection (refugee status or subsidiary protection). Figure 6 again shows the curve of register changes (from the Waiting Register to another register), this time with the number of persons having obtained international protection status. In this second curve there is a clear peak in 2016. This is a consequence of a major spike in asylum applications in 2015. In 2015, approximately 39'000 people filed a first asylum application in Belgium, three times more than the previous year (source: General Commission for Refugees and Stateless Persons). Many of them would receive international protection status over the following months (and thus the following calendar year for the most part), implying at the administrative level a change of register.

Asylum flows in 2015, during what has been described as the «asylum crisis», have been regularly compared to those of 2000 . In reality, however, there were more asylum applications in 2000 than in 2015. Nearly 39 '000 people made a first application for international protection in 2015 , compared to more than $46^{\prime} 000$ in 2000 . However, the curve for persons recognised as refugees or beneficiaries of subsidiary protection (Figure 6) does not show an increase around the year 2000. An important difference between the two years helps to explain this: recognition rates were much higher in 2015-2016 than in the early 2000s, resulting in more register changes for those recognised. In 2000, only refugee status could be granted to asylum-seekers. Of all the decisions taken in 2000, $7 \%$ (i.e., around 1'200 applications) were successful at the level of the General Commission for Refugees and Stateless Persons (CGRA). In 2015, more than $8^{\prime} 000$ applications received a favourable ruling, representing $61 \%$ of the decisions taken on merit by the CGRA in 2015 (51\% relating to refugee status and $10 \%$ to subsidiary protection). These recognition rates can be described as «cyclical», as they relate the number of positive decisions in a year to the totality of final decisions (positive and negative)

20. https://dofi.ibz.be/sites/dvzoe/fr/Pages/home.aspx. 
made in that year. However, asylum procedures take several months, and can take more than a year. A significant number of people who applied for asylum in the late 1990s and early 2000s were subsequently regularised, notably on the basis of the unreasonable length of their asylum procedure, a logical consequence of the LIFO («last in, first out») system introduced in 2000. Decisions made in a given year therefore often pertain to applications filed in the previous year(s) ${ }^{21}$.

In 2016, a large majority of register changes therefore resulted from the granting of refugee status or subsidiary protection. In that year, almost 16 '000 people moved from the Waiting Register to another register and were thus integrated into immigration statistics. Of these, 38\% were Syrian nationals, $18 \%$ Iraqi, $8 \%$ Afghan and 5\% Somali. These four nationalities were also the main nationalities of asylum-seekers in 2015.

In the end, register changes represent only a small component of immigration flows (about 10\%).

\section{Origin of immigrants: Diversifying migration dynamics}

Several migration trends have led to these changes in the profile of immigrants over the past two decades. These include a growing proportion of immigrants from the new EU member states, a proportional decrease in immigrants from the EU-15 countries, a recent significant decrease in Moroccan and Turkish immigrants, and an increase in immigrants from Western Asia. These four trends are detailed below and illustrated in Figure 8.

A first important element to highlight from Figure 7 and Table 1 is that the majority of immigrants come from the EU-28 member states (58\% of immigrants in 2017). The countries that have recently joined the EU are particularly represented in these flows. In 2004 and 2005, after the accession to the EU of 10 new states, the proportion of immigrants from these countries among all foreign immigrants was less than $10 \%$. The main country of origin then was Poland, with about 4'900 immigrants in 2005. That year Poland ranked fourth in terms of immigration flows to Belgium, a position it maintained until 2014. With the accession of Bulgaria and Romania (2007) and Croatia (2013) to the EU, the proportion of immigrants who are from new member states gradually increased,

21. For more on the differences between asylum flows in 2000 and 2015, see Myria (2016), «Focus: Asylum-seeker influx and reception policy in Belgium: Comparison of the years 2000 and 2015», in the Annual Report Migration in Figures and Act 2016, pp. 126131. 
reaching $24 \%$ in 2017 . Particularly noteworthy is the sharp rise in Romanian immigrants: they accounted for less than $1 \%$ of immigrants in 1997, compared with $12-13 \%$ since 2014 . In absolute terms, Romanian immigration has risen from a few hundred to around 18,000 in the space of 20 years, putting them at the top of the ranking.

FIGURE 7 Composition of immigration flows of foreigners in Belgium according to region of origin in 1997, 2007 and 2017)

1997: 53,062 immigrants

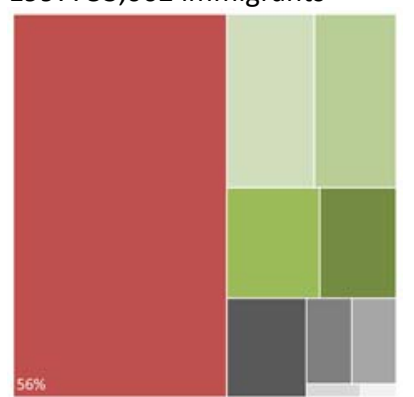

2007: 119,679 immigrants

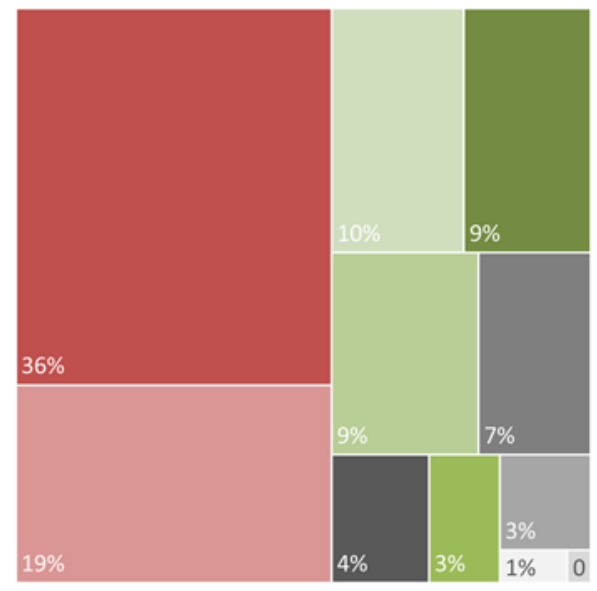


2017: 139,815 immigrants

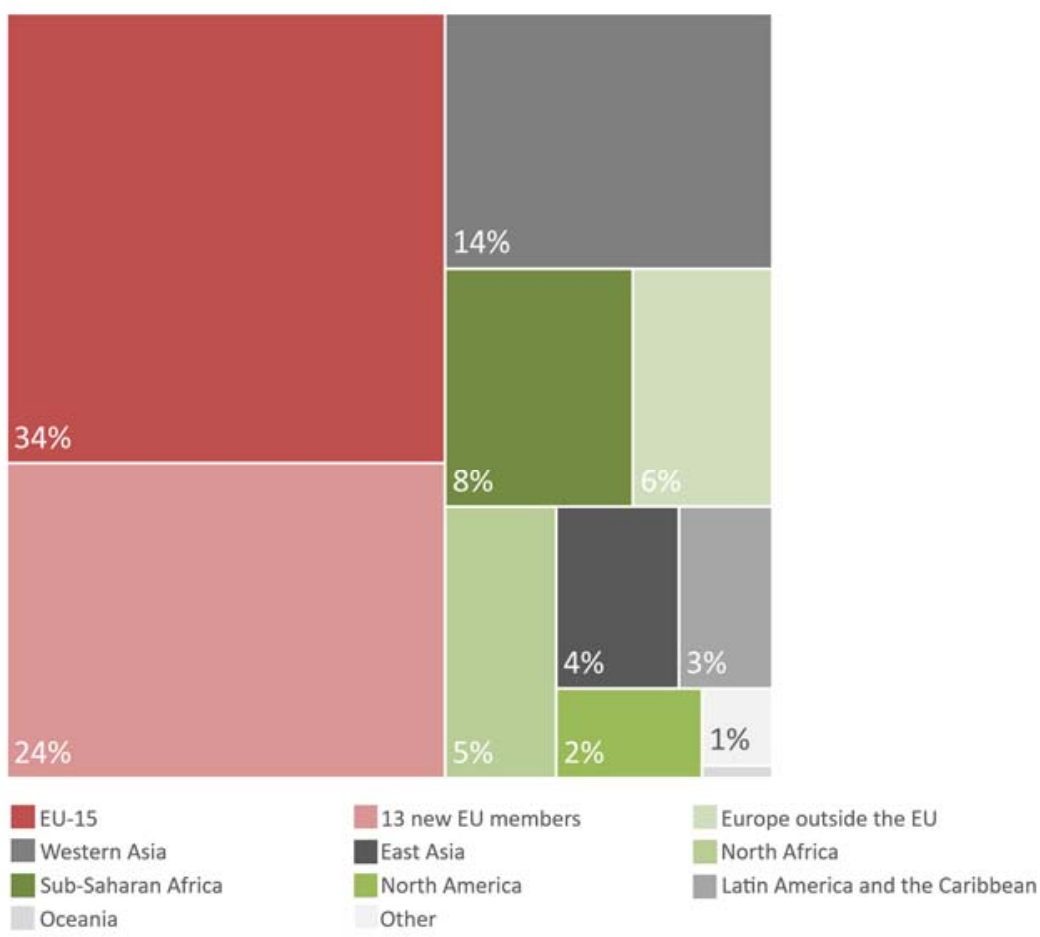

Data source: National Register, Statbel, author's calculations.

Secondly, in absolute terms, immigration from the EU-15 countries has increased steadily over the last 20 years. On the other hand, as a proportion of total foreign migration, this group has been decreasing, especially since the new member states joined the EU. The nationalities of the border countries (France and the Netherlands) accounted for $27 \%$ of immigrants in 1997, compared with $17 \%$ in 2017, with Romania taking first place in the ranking from 2014.

Thirdly, the decline in the share of people from North Africa and non-EU Europe observed over the last decade in fact reflects two nationalities in particular: Moroccans and Turks, in both relative and absolute terms. Between 2010 and 2017, Moroccan immigration fell from 10'360 to 5'225 entries (a decrease of 50\%), and Turkish immigration fell from 3'914 to 2'414 entries (a decrease of 38\%). 
TABLE 1 Main nationalities of origin of immigrants in 1997, 2007 and 2017

\begin{tabular}{|l|l|l|r|l|r|}
\hline \multicolumn{2}{|c|}{ Top 15-1997 } & \multicolumn{2}{c|}{ Top 15-2007 } & \multicolumn{2}{c|}{ Top 15 - 2017 } \\
\hline France & 7,577 & France & 13,557 & Romania & 18,048 \\
\hline The Netherlands & 6,524 & The Netherlands & 12,134 & France & 13,611 \\
\hline Morocco & 4,356 & Poland & 9,986 & The Netherlands & 9,459 \\
\hline Italy & 3,301 & Morocco & 8,638 & Italy & 6,362 \\
\hline Germany & 3,201 & Romania & 6,121 & Syria & 5,955 \\
\hline United States & 3,156 & Turkey & 3,963 & Poland & 5,787 \\
\hline United Kingdom & 2,812 & Germany & 3,697 & Morocco & 5,225 \\
\hline Portugal & 1,771 & Italy & 3,614 & Bulgaria & 5,193 \\
\hline Turkey & 1,610 & Bulgaria & 3,233 & Spain & 5,175 \\
\hline Spain & 1,325 & DR Congo & 2,902 & India & 3,812 \\
\hline Poland & 1,098 & Portugal & 2,658 & Portugal & 3,809 \\
\hline DR Congo & 905 & United States & 2,619 & Afghanistan & 3,694 \\
\hline Japan & 804 & Russia & 2,608 & Germany & 2,954 \\
\hline Greece & 744 & United Kingdom & 2,291 & Iraq & 2,548 \\
\hline Sweden & 647 & Spain & 2,273 & United States & 2,473 \\
\hline Other & 13,231 & Other & 39,385 & Other & 45,710 \\
\hline Total & $53,062^{22}$ & Total & 119,679 & Total & 139,815 \\
\hline
\end{tabular}

Data source: National Register, Statbel, author's calculations.

Finally, while immigration from West Asia was less than 3\% in 1997, it increased to 7\% in 2007 and 14\% in 2017 (Figure 7). This development is reflected in the emergence of Syrian, Afghan and Iraqi nationalities among the top 15 immigrant nationalities in 2017. Of particular note is the importance of Syrian migration since 2015. In 2016, more than 9'000 Syrian immigrants were registered, putting this country of origin in fourth place, just behind the Romanians, French and Dutch.

22. The 1997 total of immigrants in Table 1 and Figure 7 (53'062) is different from that shown in Figure 2 (57'243). Up to and including 1999, Statbel does not have figures on register changes by nationality. 
FIGURE 8 Evolution of immigration flows

for some nationalities of origin, 1997-2017

Immigrants from EU-15 countries

(France and the Netherlands)

Immigrants from North Africa (Morocco)

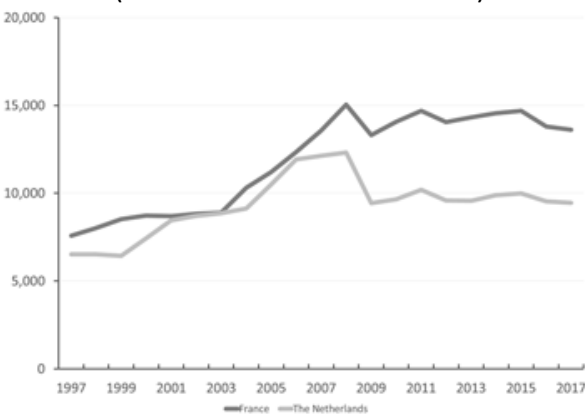
and non-EU Europe (Turkey)

Immigrants from new EU member states (Romania, Poland, Bulgaria)

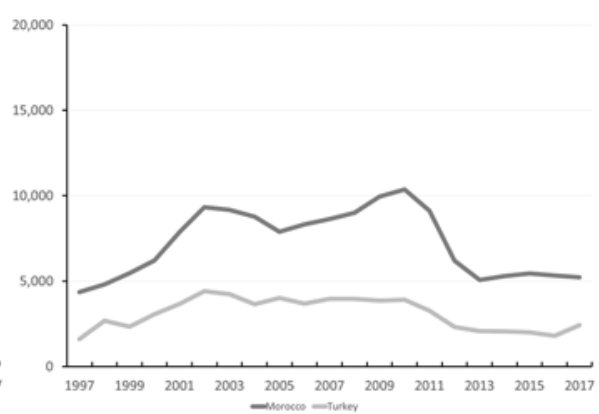

Immigrants from West Asian countries (Syria, Iraq, Afghanistan)
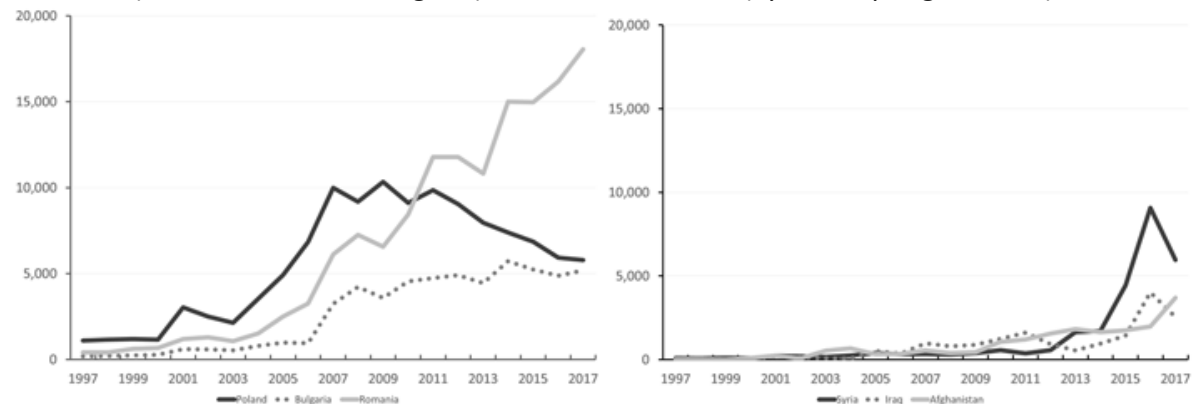

Data source: National Register, Statbel, author's calculations.

\section{Immigrant Profiles}

EU citizens have accounted for more than half of all immigrants for several years, ahead of other regions. In 1997, when the EU still had 15 member states, this proportion was 56\%. It remained stable in 2007 (55\%) following the accession of 12 new states in 2004 and 2007. Most recently, the EU-28 (excluding Belgium) accounted for $58 \%$ of the foreign immigration recorded in 2017 (Figure 7).

Behind a migration trend that has generally been on the rise since the late 1990s (Figure 1), fairly contrasting migration patterns can be identified, as illustrated in Figure 8. An examination of the main nationalities of origin of immigrants at an interval of 10 years (1997, 2007, and 2017) reveals important developments (Table 1). Some nationalities remain in the lead, such as the French; others have seen their place in the ranking 
drop, such as the Moroccans; still others are gradually beginning to appear among the 15 most represented nationalities, such as the Romanians since 2007 or the Syrians more recently. To examine the multiplicity of immigrant profiles in a little more detail, we propose to focus on four nationalities that are emblematic of this diversity: French, Moroccans, Romanians and Syrians.

\section{French immigrants: Significant and regular border migration to Belgium}

In 2017, about 1 out of 5 immigrants in Belgium came from one of the four border countries (France, the Netherlands, Germany, Luxembourg). This long-standing cross-border migration has remained relatively stable over the last two decades. In particular, France was the leading country of origin of immigrants for several consecutive years (1997-2001 and then 2004-2014). Romania took over the leading position in 2014 (see below).

In demographic terms, the age and gender distribution of the border migrant population presents a fairly typical profile for immigrants (Figure 9). There is an overrepresentation of young people of working age: more than half of French immigrants are between 20 and 34 years old when they arrive in Belgium. This characteristic is more pronounced for recent immigrants (20-34-year-olds accounted for $57 \%$ of immigrants arriving in 2017) than for immigrants two decades earlier (52\% for 1997 immigrants). Older people and young children are present in the flows but not predominant ( $8 \%$ for 0 -9-year-olds and 3\% for those aged 65 and over in 2017). The proportion of men to women is also fairly stable over time and close to parity (Figure 10). Data on the first residence permits issued to foreigners are a complementary source for studying immigrant profiles (see below, 0). Of the first 12'288 residence permits issued to French nationals in 2016, less than a third were issued for family reasons and around a third for paid employment (salaried and self-employed work). A significant proportion of first permits were also issued to students (15\%), and in $14 \%$ of cases, to migrants who could justify sufficient resources. These two categories are on average proportionally more prominent for French nationals than for other nationalities (Figure 11). 
Figure 9 Age pyramids for French, Moroccan, Romanian and Syrian immigrants for two different dates

French

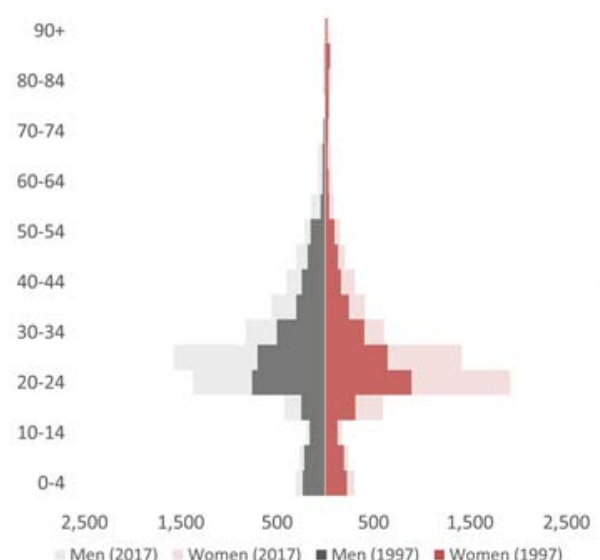

Moroccans

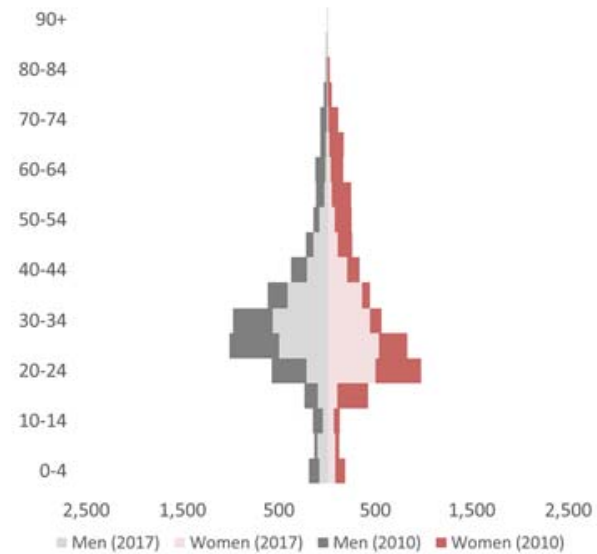

Romanians

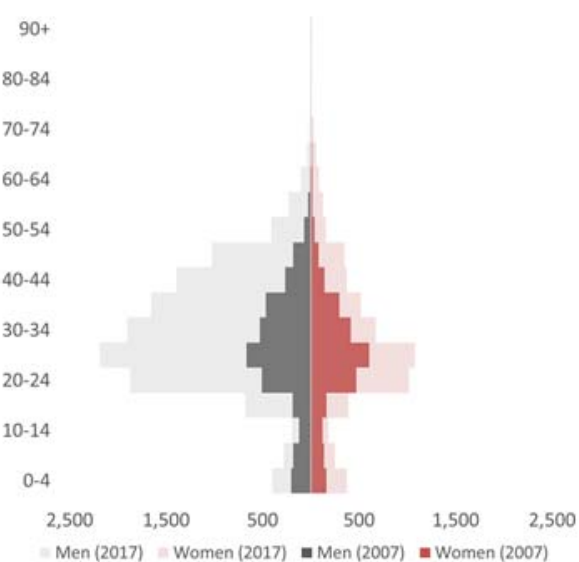

Syrians

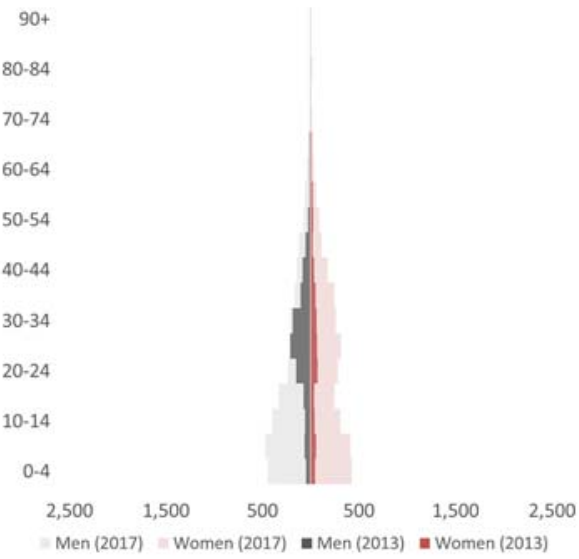

Data source: National Register, Statbel, author's calculations. 
FIGURE 10 Change in the proportion of males among immigrants of French, Moroccan, Romanian and Syrian origin for two different dates

French

Romanians
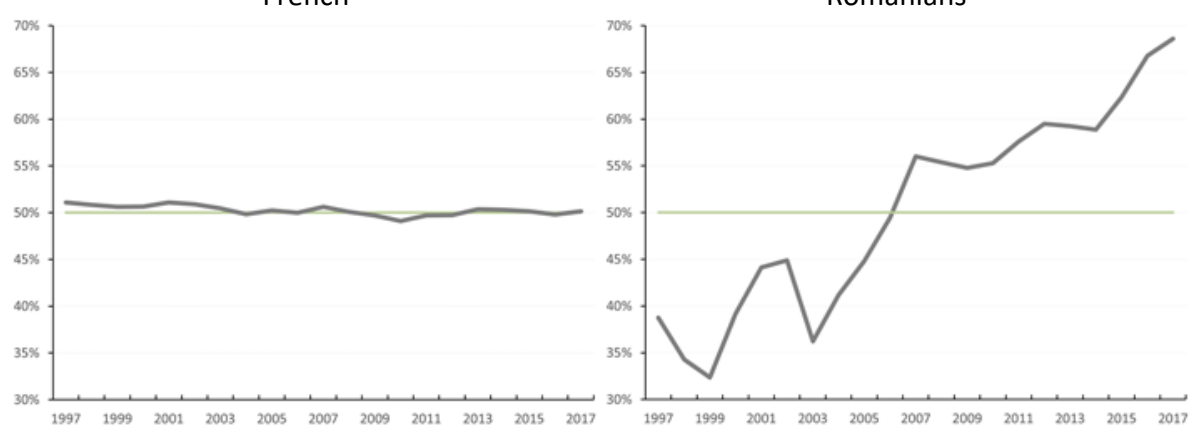

Moroccans

Syrians ${ }^{23}$

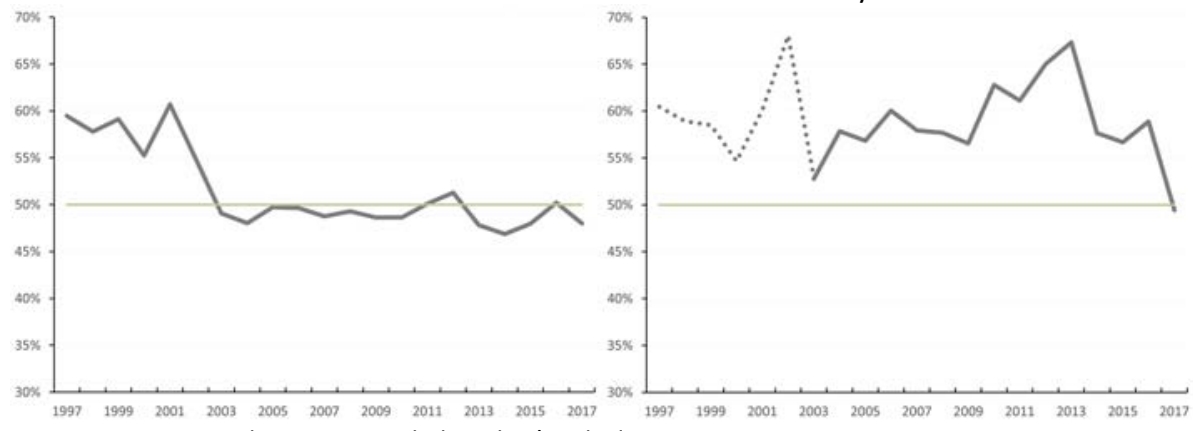

Data source: National Register, Statbel, author's calculations.

23. The dotted lines indicate that the total number of Syrian immigrants was less than 100 in those years. 
FIGURE 11 Distribution of first residence permits issued to French, Romanian and all EU citizens in 2016

EU citizens $(N=66,257)$

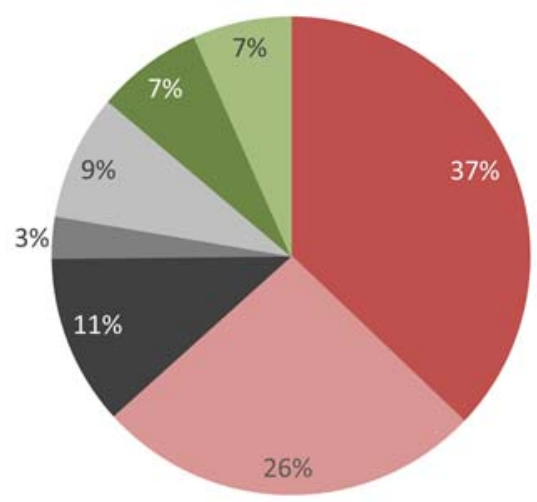

Romanians $(\mathrm{N}=12,564)$

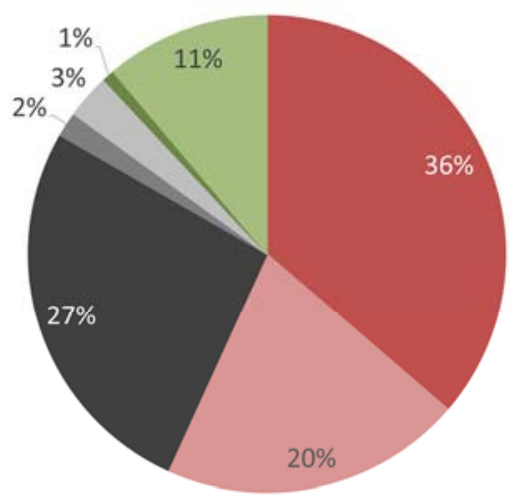

Family reasons

Job seeker

Other

Source: OE, Parliamentary Question Bulletin 135, question no. 1'278.

Romanian immigrants: An increasingly male migration, strongly linked to work

For several years, the French remained the leading immigrants to Belgium. In 2014, they were overtaken by the Romanians, who have been among the main represented nationalities ever since. In 2017, about 18'000 Romanian immigrants were registered in Belgium, more than five times more than in 2006, just before Romania's accession to the EU. This 
growth in immigration is combined with changes in demographics. While only 39\% of Romanian immigrants in 1997 were men, this proportion gradually increased (56\% in 2007) to reach 69\% in 2017 (Figure 10). The age pyramid of Romanian immigrants in 2007 shows a gender balance, while a clear imbalance in favour of men is emerging in 2017 (Figure 9). This distribution by age and gender also indicates an overrepresentation of men of working age on the labour market: in 2017, men between 20 and 39 years old represented $35 \%$ of all Romanian immigrants.

This age structure suggests that recent Romanian immigrants are strongly motivated by work. This is also revealed by the figures on first residence permits (Figure 11). Among the first 12'564 permits issued to Romanians in 2016, 47\% involved a paid activity. The proportion of first permits issued to self-employed people is particularly striking (27\%), and well above the average for all EU nationalities combined (11\%). Romanians clearly stand out from other EU nationalities, as they alone account for $44 \%$ of the first permits issued in the context of self-employment. In the 2017 report Monitoring socio-économique (SPF-UNIA, 2017), detailed information is presented on the sectors of activity of the self-employed from the new EU member states. It emerges that the most common sectors of activity for this group of countries are construction for men and cleaning via domestic work vouchers for women.

\section{Moroccan immigrants: Long-standing migration recently slowed by family reunification being made more difficult}

Non-European immigration to Belgium is clearly marked by immigration from Morocco. Moroccan immigration is long-standing for Belgium, representing one of the main immigration flows for more than fifty years. Like a number of migratory flows, it was strongly affected by the end of labour immigration as early as the mid-1970s, gradually picking up again in the mid-1980s. However, in contrast to other immigrants, the end of the 1990s was characterised for Morocco by a significant increase in entries into Belgium. Between 1997 and 2015, Morocco was by far the leading third country of origin for immigrants. In 2002 and 2003, Morocco even topped the overall ranking, surpassing immigrants from France and the Netherlands. It was only from 2016 that the situation changed: in 2016 and 2017, Syria had pulled ahead of Morocco, with very distinct immigration level (see below).

When between 1997 and 2002 the number of Moroccan immigrants doubled (Figure 8). The dynamics of family reunification were the main rea- 
son for this increase. Between 2002 and 2010, the annual number of immigrants from Morocco fluctuated between 8'000 and 10'000, or about $10 \%$ of all foreign immigrants to Belgium. Since 2010, however, there has been a sharp decline in these flows. Between 2010 and 2017, the number of immigrants to Belgium halved from 10'000 to around 5'000 annual immigrants.

Data on the issuance of first residence permits provide some additional information on this trend over the last decade. In 2010, the overwhelming majority (75\%) of the first residence permits issued to Moroccan nationals were for family reasons (Figure 12). In 2016, this proportion was lower, but still significant (68\%). The drastic decrease in the number of first residence permits for family reasons between 2010 and 2016 is remarkable, especially for people aged between 20 and 59 (Figure 13).

Figure 12 Breakdown of first permits issued to Moroccans by reason in 2010

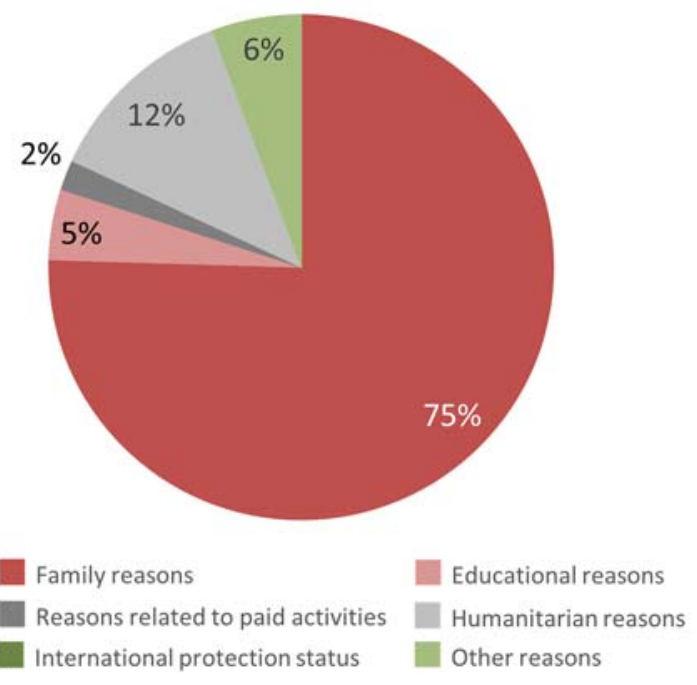

Source: Office des Étrangers, Eurostat, author's calculations. 
FIGURE 13 Changes in the number of first permits issued for family reasons by age group for Moroccans, 2010-2016

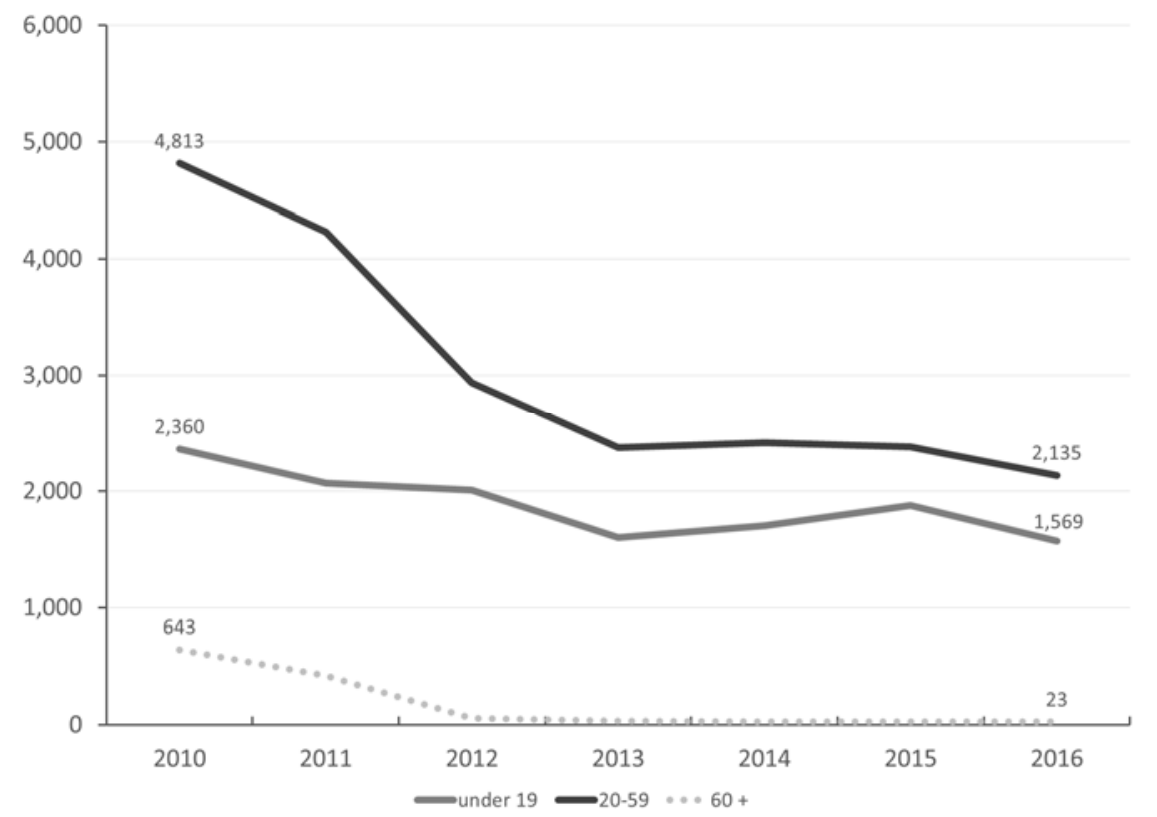

Source: Office des Étrangers, Eurostat, author's calculations.

Politically, this pivotal period corresponds to important changes in the area of family reunification. A new Act, adopted on 8 July 2011 and coming into force on 22 September of the same year, significantly modified the rules of access to family reunification. This Act created four different regimes for family reunification, depending on the nature of the residence permit (limited or unlimited) and the nationality of the person who is already in Belgium (Belgian, EU or non-EU). In particular, the Act imposes resource requirements on Belgians and non-EU nationals who wish to bring their spouse and excludes the possibility of bringing in the ascendants of Belgians who have reached adult age. It also increases the age requirement for members of the couple from 18 to 21 years for certain categories of persons ${ }^{24}$. Given the Moroccan presence in Belgium and the propensity of Moroccan nationals, who have sometimes become Belgians, to be joined by their families, these new measures particularly affect those of Moroccan origin. Furthermore, the Act interprets the bilateral

24. Cf. the Act of 15 December 1980 on access to the territory, residence, establishment and removal of foreigners, Articles 10, 10bis, 40 bis and 40 ter. 
agreements concluded with certain countries (including Morocco) as applying only to families of the Moroccan nationals who reside in Belgium under such agreements, whereas they previously applied to all persons with that nationality.

Syrian immigrants: Following the asylum flows, room for family reunification

In recent years, registered Syrian immigration to Belgium has risen sharply, placing Syria among the five most frequent countries of origin in 2016 and 2017. The fact that these immigrations represent $7 \%$ of the total foreign immigration to Belgium in 2016 is a clear indication that asylum flows are perceptible through immigration statistics. However, not all of these people arrived in 2016 and 2017, nor did they all apply for asylum. As a reminder, only asylum-seekers who have been granted international protection status are counted in immigration statistics once their status has been officially granted. Furthermore, the granting of international protection status is sometimes followed by an application for family reunification with one or more family members who have remained in the country of origin. Beneficiaries of family reunification with a refugee are therefore also included in the immigration flows (see below).

In 2016, more than 9'000 Syrian immigrants were registered in Belgium, twice as many as in 2015 and five times as many as in 2014. In 2016, Syria was therefore the fourth most important country of origin of immigrants in Belgium, after Romania, France and the Netherlands. This development is quite unprecedented, since historically the main immigration flows to Belgium were mainly from EU citizens, with the exception of Moroccan and Turkish nationals, who have always played an important role. From 2017 immigration flows from Syria started to fall again (around 6'000), following the trend in asylum applications with a few months' delay.

The presence of Syrians in immigration flows to Belgium seems to be coincidental. It is not part of the migratory flows that Belgium has historically maintained with certain countries (France, Morocco), nor is it part of a pattern of openness and economic exchanges (Romania), but rather reflects a state of crisis in the country of origin and a major need for protection for this population. 
FIGURE 14 Breakdown of the reasons for the first permits issued to Syrians in 2016

141

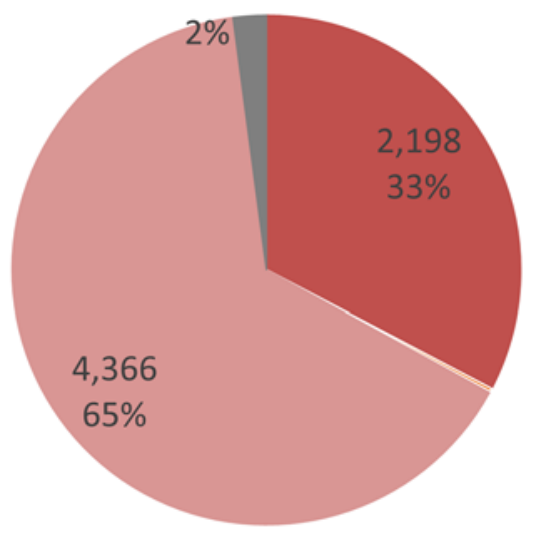

Family reasons

Refugee status and subsidiary protection

Other

Source: Aliens Office, Eurostat, author's calculations.

In demographic terms, there has been a rapid change in the composition of the Syrian population arriving in Belgium. In 2013, the year from which a significant number of Syrian immigrants (1'640) are observed, twothirds were men and half were aged between 20 and 34. Four years later, the distribution by age and sex has changed significantly (Figure 9). There is a balance between men (49\%) and women (51\%) and there are about as many young people under 18 years of age (49\%) as there are over 20 years of age. In 2013, only 21\% of immigrants were under the age of 18 . These changes in terms of age and gender structure also reflect changes in the type of migration. In 2013, more than $80 \%$ of Syrians who had been issued a first residence permit had been granted international protection status (refugee or subsidiary protection) following an asylum procedure in Belgium. For the rest, $14 \%$ had been granted this first permit for family reasons, and 3\% for humanitarian reasons (Figure 15) ${ }^{25}$. In 2017, the ratio changes: $65 \%$ are beneficiaries of international protection and 33\% obtained their first permit for family reasons (Figure 14). It should be noted that among the latter category some are children born in Belgium (Myria, 2017).

25. A few Syrians have also obtained a first residence permit for reasons related to education or gainful employment, but these represent less than $1 \%$ and are therefore not visible in this Figure. 
FIGURE 15 Changes in the number of first permits issued for family reasons and following the obtention of international protection for Syrians, 2010-2016

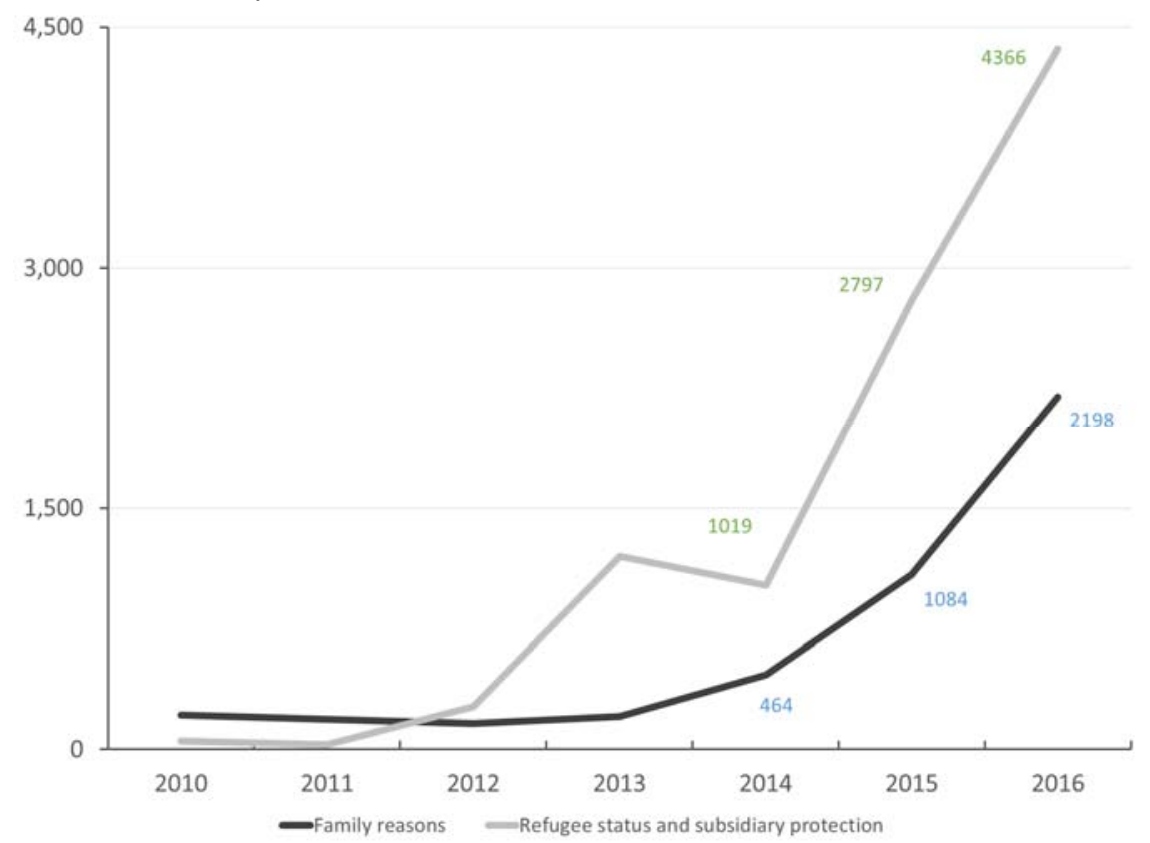

Source: Office of Foreigners, Eurostat, author's calculations.

While the majority of Syrian immigration in recent years reflects asylum flows, there is still a large number of Syrian immigrants who arrived by other routes or who were born in Belgium (and counted in the first residence permits). The various indicators presented make this clear: the increase in asylum flows of Syrians takes place alongside an increase in family reunification. These developments are undoubtedly partly linked to the more favourable conditions granted to recognised refugees and beneficiaries of subsidiary protection during the first year of their recognition for be joined by their family members (spouse and children).

It should be noted that in the context of family reunification, the material conditions do not apply to recognised refugees and beneficiaries of subsidiary protection who bring their spouse and/or child(ren) within one year of their recognition. That said, family reunification, even when facilitated for this category of individuals, often remains complicated. The application for family reunification must be submitted from abroad by the 
person who wishes to join a family member already in Belgium. In countries ravaged by war, access to a Belgian diplomatic post is often difficult ${ }^{26}$.

\section{Conclusion}

Since 1997, international migration in Belgium has undergone many changes. While emigration out of Belgium has doubled since the early 2000 s, the end of the 1990s was characterised by increasing immigration of foreigners into Belgium. The number of entries of foreigners has indeed reached a historically high level, reaching between 120 '000 and $140^{\prime} 000$ annual immigrants between 2007 and 2017. Behind this acceleration in migratory exchanges to Belgium, various migration dynamics are at work and are studied in this article.

A first important analysis focuses on the components of migration flows in Belgium. In particular, it has been shown that register changes (moving from the Waiting Register to another register), while representing only a minority of immigration flows (around 10\%), illustrate specific migration profiles: persons benefiting from international protection (refugee status or subsidiary protection) as well as regularised persons. It is obviously important to take this population into account, even with a certain delay, in immigration flow statistics, but it should be noted that behind the scenes, all irregular migrants who do not obtain residence status are not included in these official statistics, and as such are not taken into account. Specific studies should be carried out on this population in order to cover migration in Belgium more comprehensively.

The analysis of the origins of immigrants indicates first of all that the EU is ahead of the other world regions, accounting for more than half of all immigrants for several years. Alongside this strong trend, several migration dynamics are at work, giving rise to changes in the profiles of immigrants. These include a growing proportion of immigrants from the new EU member states, a proportional decrease in immigrants from the EU15 countries, a recent significant decrease in Moroccan and Turkish immigrants, and an increase in immigrants from Western Asia, particularly from countries at war. To illustrate these changes and this diversity of

26. For a detailed analysis of the difficulties encountered by beneficiaries of international protection in using family reunification to bring their family to Belgium, see Myria (2018). 
profile, four nationalities were highlighted: French immigrants, a group characterised by a stable and numerically significant border migration; Romanian immigrants, reflecting an increasingly male and strongly work-related migration; Moroccan immigrants, illustrating a longstanding but recently slowed migration due to a political tightening of family reunification policies; and finally, Syrian immigrants, characterised by an asylum migration recently mixed with family reunification.

In short, behind an overall upward trend, several indicators suggest that the current context is less and less favourable to the opening of the Belgian borders. Rather than a linear trend, two phases seem to emerge. In the first phase, between the end of the 1990s and 2010, several indicators reflect a certain openness to international mobility. The successive accessions of new member states to the EU lead to more intensive exchanges with new countries, and the mobility of EU citizens largely fuels the immigration flows to Belgium. Two acts enacted 10 years apart led to the regularisation of several tens of thousands of people with precarious or illegal residence, and in the space of ten years, the number of immigrants more than doubled.

Since 2010, however, a second phase has begun with a new migratory context in Belgium. The number of immigrants from abroad is fluctuating without really increasing. Regularisation operations such as those that the then Belgian governments put in place in 1999 and 2009 are no longer on the agenda. Migration policy on family reunification is becoming more stringent, with direct consequences for longstanding migration flows in Belgium. More recently, asylum flows have increased, allowing access to Belgian territory for more persons in need of protection. In spite of their visibility in the media, however, these streams represent only a minority of the total flows.

\section{References}

Before and After (2008), La situation sociale et économique des personnes ayant bénéficié de la procédure de régularisation en 2000 (loi du 22 décembre 1999), Centrum voor Sociaal Beleid - Herman Deleeck University of Antwerp, Groupe d'études sur l'ethnicité, le racisme, les migrations et l'exclusion, ULB. 182 p., http://www. myria.be/files/BeforeandAfter-FR.pdf.

CAstles S., De HaAs H., Miller M. J. (2014), The Age of Migration: International Population Movements in the Modern World, Red Globe Press, $420 \mathrm{p}$. 
Centre pour l'égalité des chances et la lutte contre le racisme (CECLR) (2011), Annual Report Migration, Brussels, 202 p., https://www.myria.be/files/Migrationrapport-2011.pdf.

Direction générale Emploi et marché du travail (2003), L'immigration en Belgique. Effectifs, mouvements et marché du travail, Ed. Service public fédéral Emploi, Travail et Concertation sociale, 75 p., http://www.belspo.be/belspo/organisation/publ/ pub_ostc/agora/ragee058_fr.pdf.

EgGERICKX T. (2006), «Migrations internationales et populations de nationalité étrangère : quelques aspects démographiques», KHADER B. et al. (ed), Penser l'immigration et l'intégration autrement, Belgian Inter-University Initiative on Immigration and Integration, Brussels, 18-19 October 2004, Bruylant, pp. 29-71.

Eggerickx T., Hermia J.-P. (2005), «Migrations internationales et populations d'origine étrangère en Belgique», GRIMEAU J.-P., DeBoosere P., EGGERICKX T. et al. (eds), Atlas de Belgique, Population, Academia Press, Brussels, pp. 80-90.

EASO (2019), EU+ Asylum Trends 2018 Overview, 15 p.

Hatton T. (2004), "Seeking Asylum in Europe», Economic Policy, 19 (38), pp. 5-62, https://doi.org/10.1111/j.1468-0327.2004.00118.x.

Lafleur J.-M., Martiniello M., ReA A. (2015), «Une brève histoire migratoire de la Belgique», SIMON G. (ed), Dictionnaire des migrations internationales, Paris, Armand Collin, pp. 24-29, http://orbi.ulg.ac.be/handle/2268/184933.

MARTEns A. (1976), Les immigrés. Flux et reflux d'une main-d'œuvre d'appoint, Louvain, P.U.L. and Éditions Vie Ouvrière, 208 p.

Martiniello M., Rea A., Timmerman C., Wets J. (eds) (2010), New Migration and New Migrants in Belgium, Ghent, Academia Press.

Morelu A. (2004), Histoire des étrangers et de l'immigration en Belgique : de la Préhistoire à nos jours, Brussels, Couleur livres, $416 \mathrm{p}$.

Myria (2013), Migrations et populations issues de l'immigration en Belgique. Rapport statistique et démographique, Brussels, Publications of the Federal Migration Centre, 175 p., http://www.myria.be/files/Rapport-statistique-demographique-2013.pdf.

Myria (2015), Immigré, étranger, Belge d'origine étrangère : de qui parle-t-on ?, Myriatics, 2, 5 p., http://www.myria.be/files/Myriatics2_layout.pdf.

Myria (2016), La migration en chiffres et droits. Annual Report, Brussels, Publications of the Federal Migration Centre, 256 p., https://www.myria.be/files/MIGRA16_FR_ AS.pdf.

Myria (2017), La migration en chiffres et droits. Annual Report, Brussels, Publications of the Federal Migration Centre, 185 p., http://www.myria.be/fr/publications/lamigration-en-chiffres-et-en-droits-2017.

Myria (2018), La migration en chiffres et droits. Annual Report, Brussels, Publications of the Federal Migration Centre, 168 p., https://www.myria.be/files/MIGRA2018_ FR_AS_1.pdf. 
SALt J. (2011), "Trends in Europe's International Migration», RECHEL B. et al. (eds), Migration and health in the European Union, Berkshire, UK, Open University Press, pp. 17-35.

SPF Emploi, Travail et Concertation sociale et UNIA (Centre interfédéral pour l'égalité des chances) (2017), Socio-economic Monitoring 2017, Labour Market and Origins, 188 p., https://www.unia.be/files/Documenten/Publicaties_docs/1215_ UNIA_Monitoring_2017_-_FR-Anysurfer.pdf.

VAN Mol C., DE VALK H. (2016), «Migration and Immigrants in Europe: A Historical and Demographic Perspective», GarcÉs-Mascareñas B., PenninX R. (eds), Integration Processes and Policies in Europe: Contexts, Levels and Actors, Springer, pp. 31-55, https://doi.org/10.1007/978-3-319-21674-4_3. 